\title{
A história de inversão do aulacógeno do Paramirim contada pela sinclinal de Ituaçu, extremo sul da Chapada Diamantina (BA)
}

\author{
Simone Cerqueira Pereira Cruz \& Fernando Flecha Alkmim ${ }^{1}$
}

\begin{abstract}
Resumo O Aulacógeno do Paramirim, localizado na porção nordeste do Cráton do São Francisco, é um rifte parcialmente invertido e representa o sítio deposicional das duas maiores unidades de cobertura, os supergrupos Espinhaço e São Francisco, de idades paleo/mesoproterozóica e neoproterozóica, respectivamente. A inversão do aulacógeno resultou em um sistema de falhas e dobras com trend NNW-SSE que domina o cenário estrutural regional. A idade da inversão e seu mecanismo vêm persistindo ao longo dos anos como matéria de debate na literatura geológica brasileira. Localizada no extremo sul do Aulacógeno, a sinclinal de Ituaçu é uma depressão sinformal que pertence ao conjunto de estruturas de inversão dominantes. Repousando sobre o embasamento, a sinclinal de Ituaçu envolve todas as unidades sedimentares proterozóicas de preenchimento do aulacógeno. Por causa disso, a sinclinal de Ituaçu pode ser vista como uma miniatura do Aulacógeno do Paramirim, representando um laboratório natural para a análise das estruturas de inversão e teste de hipóteses relativas à sua evolução tectônica. A investigação estrutural detalhada baseada em dados de campo permitiu documentar duas famílias de estruturas relacionadas com essa inversão. A família mais antiga, $\mathrm{D}_{\mathrm{a}}$, marca o descolamento entre a cobertura e o substrato cristalino, sendo constituída por falhas e dobras que mostram uma orientação geral segundo WSWENE e vergência dirigida para NNE. A família mais jovem, $D_{p}$, compreende um rico e diversificado acervo de estruturas com trend NNW-SSE, vergência para ENE. Está representado por falhas e dobras que estruturam a sinclinal e que foram desenvolvidas inicialmente acima e no limite entre o substrato cristalino e a cobertura, seguido por envolvimento do embasamento na deformação. Ambas as famílias de estruturas afetam os carbonatos da Formação Salitre, a mais jovem unidade de preenchimento do aulacógeno, indicando assim uma idade máxima neoproterozóica para a inversão da porção sul do Aulacógeno do Paramirim. As estruturas $\mathrm{D}_{\mathrm{a}}$ foram interpretadas como uma conseqüência da migração do front de deformação brasiliana para norte, em direção ao aulacógeno, da mesma forma como documentada em muitas outras áreas próximas à borda sudeste do Cráton do São Francisco. As estruturas $D_{p}$ refletem o fechamento frontal do aulacógeno, em função a um encurtamento geral WSW-ENE, que foi provavelmente induzida pelas colisões durante a colagem Brasiliana-Panafricana.
\end{abstract}

Palavras-chave: sinclinal, Cráton do São Francisco, Chapada Diamantina, Neoproterozóico, evento brasiliano.

\begin{abstract}
The Ituaçu Syncline, Extreme-South of the Chapada Diamantina (Bahia) and the Inversion of the Paramirim Aulacogen. The Paramirim aulacogen located in the northern São Francisco craton is a partially inverted rift, which represents the depositional site of two major craton cover units, the Espinhaço and São Francisco Supergroups of paleo/mesoproterozoic and neoproterozoic ages, respectively. Inversion of the aulacogen resulted in a system of NNW-SSE-trending faults and folds that dominates its structural picture. The age of inversion and its driving mechanism persist over the years as matter of debate in the Brazilian geological literature. Located in the southern end of the aulacogen, the Ituaçu syncline is a synformal depression that belongs to set of the dominant inversion structures. Besides basement, the Ituaçu syncline involves all Proterozoic sedimentary units in very good exposure conditions. Because of that, the Ituaçu syncline can be viewed as a miniature of the Paramirim aulacogen, thereby representing a natural laboratory for both analysis of inversion structures and test of hypothesis concerning its tectonic evolution. A detailed and field based structural investigation performed in the syncline area allows us to document two distinct families of inversion structures. The older family, $\mathrm{D}_{\mathrm{a}}$, consists of a system of thin-skinned faults and folds, which shows a general WNW-ESE orientation and a systematic NNE-directed vergence. The younger family, $\mathrm{D}_{\mathrm{p}}$, comprises a very rich and diverse set of NNW-SSE-trending and ENE-verging fabric elements, associated with thin-skinned and basement-involved faults and folds, among them the Ituaçu syncline as a whole. Both families of structures affect the carbonates of the Salitre Formation, the youngest among the aulacogen fill units, indicting thus a maximum late Neoproterozoic age for the inversion of the southern Paramirim aulacogen. We interpret the $\mathrm{D}_{\mathrm{a}}$ structures as a consequence of the migration of Brasiliano deformation front further north, into the aulacogen trough, in the same way as document in many other areas close to São Francisco craton boundaries. The $\mathrm{D}_{\mathrm{p}}$ structures clearly reflect the frontal closure of the aulacogen, due to an overall WSW-ENE oriented compression, which was probably induced by the collisions the São Francisco craton became involved during the Brasiliano-PanAfrican tectonic collage.
\end{abstract}

Keywords: syncline, São Francisco craton, Chapada Diamantina, Neoproterozoic, brasiliano event.

1 - Departamento de Geologia, Escola de Minas, Universidade Federal de Ouro Preto, Morro do Cruzeiro, Ouro Preto (MG), Brasil.

E-mails: simoneufbag@mail.com, alkmim@degeo.ufop.br 
INTRODUÇÃOO O Aulacógeno do Paramirim (Pedrosa-Soares et al. 2001) corresponde, in totum, ao Aulacógeno do Espinhaço, caracterizado por Moutinho da Costa \& Inda (1982). Representa uma grande feição morfoestrutural da porção norte do Cráton do São Francisco que engloba a serra do Espinhaço Setentrional, os vales do Paramirim e do São Francisco e a Chapada Diamantina. Possui como unidades características os Supergrupos Espinhaço e São Francisco e corresponde a um par de riftes paleo/meso e neoproterozóico superpostos e parcialmente invertidos que envolvem essas duas unidades estratigráficas maiores (Schobbenhaus 1996).

A Sinclinal de Ituaçu é uma das estruturas dominantes do extremo sudoeste da Chapada Diamantina e envolve rochas do embasamento, do Complexo Lagoa Real, do Grupo Paraguaçu (Supergrupo Espinhaço) e do Grupo Una (Supergrupo São Francisco) (Fig. 1). Nessa sinclinal encontram-se elementos tectônicos relativos a todas as fases de deformação registradas na porção sul do Aulacógeno do Paramirim, guardando entre si relações notáveis de corte e superposição e, muito importante, afetando as rochas mais jovens do preenchimento do aulacógeno, os carbonatos da Formação Salitre. A Sinclinal de Ituaçu constitui, dessa forma, uma miniatura do cenário tectônico da porção sul do Aulacógeno do Paramirim e, devido à qualidade das exposições, representa um excelente laboratório natural para a caracterização dos elementos do seu arcabouço e, conseqüentemente, para a formulação de um modelo para sua evolução. Em função disso, um estudo estrutural, baseado na cartografia na escala 1:100.000 e na confecção de transecções de detalhe, foi levado a efeito na região da sinclinal e áreas imediatamente adjacentes. No presente artigo descrevem-se os componentes do arcabouço estrutural da Sinclinal de Ituaçu, ordenados de acordo com as sucessivas fases de deformação em que foram nucleados que, dessa forma, compõem uma história evolutiva da etapa de inversão da porção sul do Aulacógeno do Paramirim.

CONTEXTO REGIONAL Segundo Almeida (1977), o Cráton do São Francisco é uma das diversas porções do continente sulamericano que foram poupadas das orogenias Brasilianas que tiveram lugar no Neoproterozóico. Corresponde, em grande parte, a uma plataforma antiga que se encontra bordejada por faixas orogênicas cujas vergências são dirigidas para o seu interior. O cráton hospeda uma série de feições tectônicas regionais, dentre elas o Aulacógeno do Paramirim, que ocupa grande parte da sua porção setentrional, exposta no estado da Bahia.

De acordo com a definição anteriormente apresentada, o Aulacógeno do Paramirim envolve o embasamento e as duas grandes unidades proterozóicas da cobertura cratônica, os supergrupos Espinhaço e São Francisco.

Consideram-se como embasamento do Cráton do São Francisco as unidades mais antigas que $1,8 \mathrm{Ga}$, que compreende rochas gnáissicas e migmatíticas de idades arquena e paleoproterozóica, bem como associa- ções supracrustais dessas mesmas idades (Brito-Neves et al. 1980, Cordani et al. 1985, Marinho 1991, Martin et al. 1991, Santos-Pinto 1996, Bastos-Leal 1998). Na porção norte do cráton, essas rochas encontram-se intrudidas por granitóides de 1,75 Ga (Maruèjol et al. 1987, Turpin et al. 1988, Cordani et al. 1992, Babinski et al. 1994, Pimentel et al. 1994), os quais foram, posteriormente, albitizados, deformados e gnaissificados (Costa et al. 1985, Lobato \& Fyfe 1990, Cruz \& Alkmim 2002, Cruz 2004). Todo o conjunto de rochas graníticas, gnáissicas e albitíticas intrusivas no embasamento foram agrupadas no Complexo Lagoa Real por Costa et al. (1985).

O Supergrupo Espinhaço engloba uma sucessão de sedimentos essencialmente terrígenos, com contribuições de vulcânicas ácidas a intermediárias na base, que ocorre na Chapada Diamantina e na serra do Espinhaço Setentrional (Barbosa \& Dominguez 1996, Danderfer Fo 2000) (Fig. 2). É intrudido por um grande número de diques e sills máficos, de idade préSupergrupo São Francisco (Babinski et al. 1993). O seu metamorfismo atinge, no máximo, condições de fácies xisto verde. A idade para o magmatismo ácido a intermediário da porção basal foi definida em $1.748 \pm 1 \mathrm{Ma}$ (Babinski et al. 1994). Nos sedimentos da Formação Caboclo, Macedo \& Bonhomme (1984) encontraram idade $\mathrm{Rb} / \mathrm{Sr}$ em torno de $960 \mathrm{Ma}$, que foi atribuída à sua diagênese.

O Supergrupo São Francisco, por sua vez, compreende um conjunto de rochas terrígenas e carbonáticas depositadas em ambiente marinho com influência glaciogênica, que grada para condições plataformais. $\mathrm{Na}$ base ocorrem diamictitos, ardósias laminadas, arenitos argilosos e arenitos finos formados sobre influência glaciogênica (Formação Bebedouro) (Guimarães 1996, Dominguez 1996). Esses sedimentos são recobertos por rochas carbonáticas, intercaladas com pelitos, todos depositados em ambiente marinho raso, com constante agitação de ondas ou em planície de maré (Formação Salitre) (Leão et al. 1992). Uma correlação estratigráfica entre as rochas do Supergrupo São Francisco na serra do Espinhaço Setentrional e na Chapada Diamantina é mostrada na figura 2. Datações realizadas pelo método $\mathrm{Rb} / \mathrm{Sr}$ e K/Ar em argilas da Formação Bebedouro, na Chapada Diamantina, forneceram idades em torno de $958 \pm 38$ e $900 \mathrm{Ma}$ (Macedo \& Bonhomme 1984). Para a Formação Salitre, os dados $\mathrm{Rb} / \mathrm{Sr}$ em argilas autigênicas dos carbonatos apontam idades de deposição entre 750-850 Ma (Macedo \& Bonhomme 1984, Misi \& Veizer 1996, Toulkeridis et al.1999).

Na porção ocidental da Chapada Diamantina, as rochas do embasamento, Complexo Lagoa Real, Supergrupos Espinhaço e São Francisco encontram-se estruturadas segundo um cinturão de cavalgamentos e dobramentos vergentes para leste com envolvimento do embasamento na deformação da cobertura (Danderfer $\mathrm{F}^{\circ}$ 1990, Cruz et al. 1998, Bento 2001). Os trabalhos realizados nessa porção do aulacógeno demonstram a existência de três fases principais de deformação. A primeira está representada por um conjunto de zonas de 


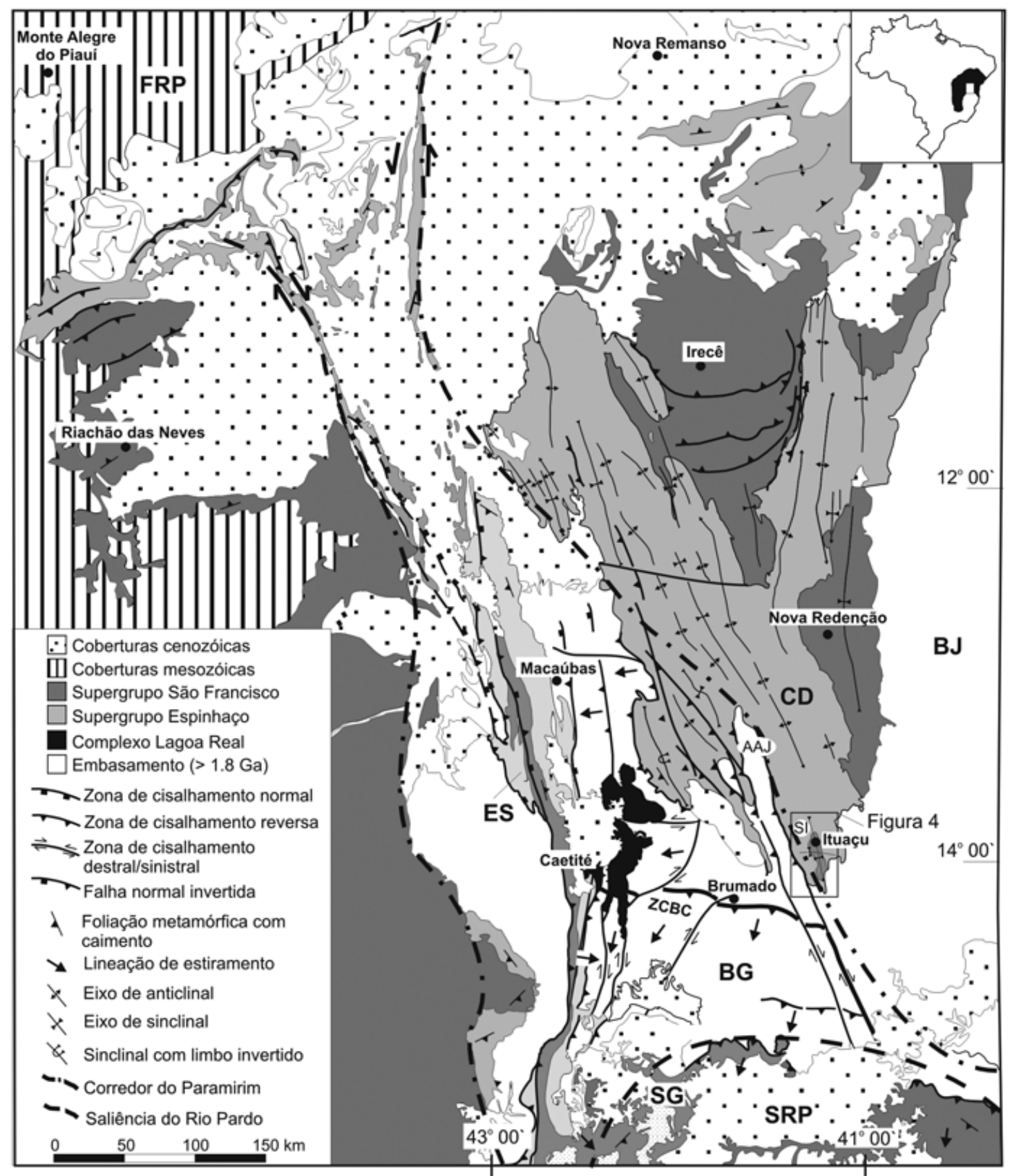

Figura 1 - Localização da Sinclinal de Ituaçu na porção sul do Aulacógeno Paramirim. O quadro representa a localização da Figura 4. BG: Bloco Gavião, BJ: Bloco Jequié, ZCBC: Zona de cisalhamento Brumado-Caetité, ES: Espinhaço Setentrional, CD: Chapada Diamantina, FRP: Faixa Rio Preto, SRP: Saliência do Rio Pardo (Faixa Araçuai), SI: Sinclinal de Ituaçu, AAJ: Anticlinal de Abaira-Jussiape, SG-Serra Geral. Mapa confeccionado a partir de Schobbenhaus et al. (1981) e Barbosa \& Dominguez (1996).

cisalhamento e dobras orientadas segundo E-W, ambos vergentes para norte. Essas estruturas são penetrativas a sul do paralelo de $14^{\circ}$ 00'S (Cruz \& Alkmim 2006).

A segunda fase está representada por um conjunto de falhas e dobras segundo NNW/SSE, com vergência para leste (Moutinho da Costa \& Inda 1982, Danderfer Fo 1990, Cruz \& Alkmim 2006). A intensidade de deformação e metamorfismo associada a essa fase diminuiriam para leste, em direção à Chapada Diamantina Oriental. De uma maneira geral, na Chapada
Diamantina Ocidental as estruturas deformacionais experimentam um aumento da deformação em direção ao sul (Moutinho da Costa \& Inda 1982, Danderfer Fo 1990, Cruz \& Alkmim 2006). De acordo com aqueles autores, acima do paralelo $12^{\circ} 30^{\prime} \mathrm{S}$, a cobertura repousa subhorizontalmente sobre o embasamento. Em direção ao sul, as rochas sedimentares do Supergrupo Espinhaço seriam progressivamente mais deformadas e inversões estratigráficas seriam encontradas. Essas estruturas são penetrativas regionalmente. 


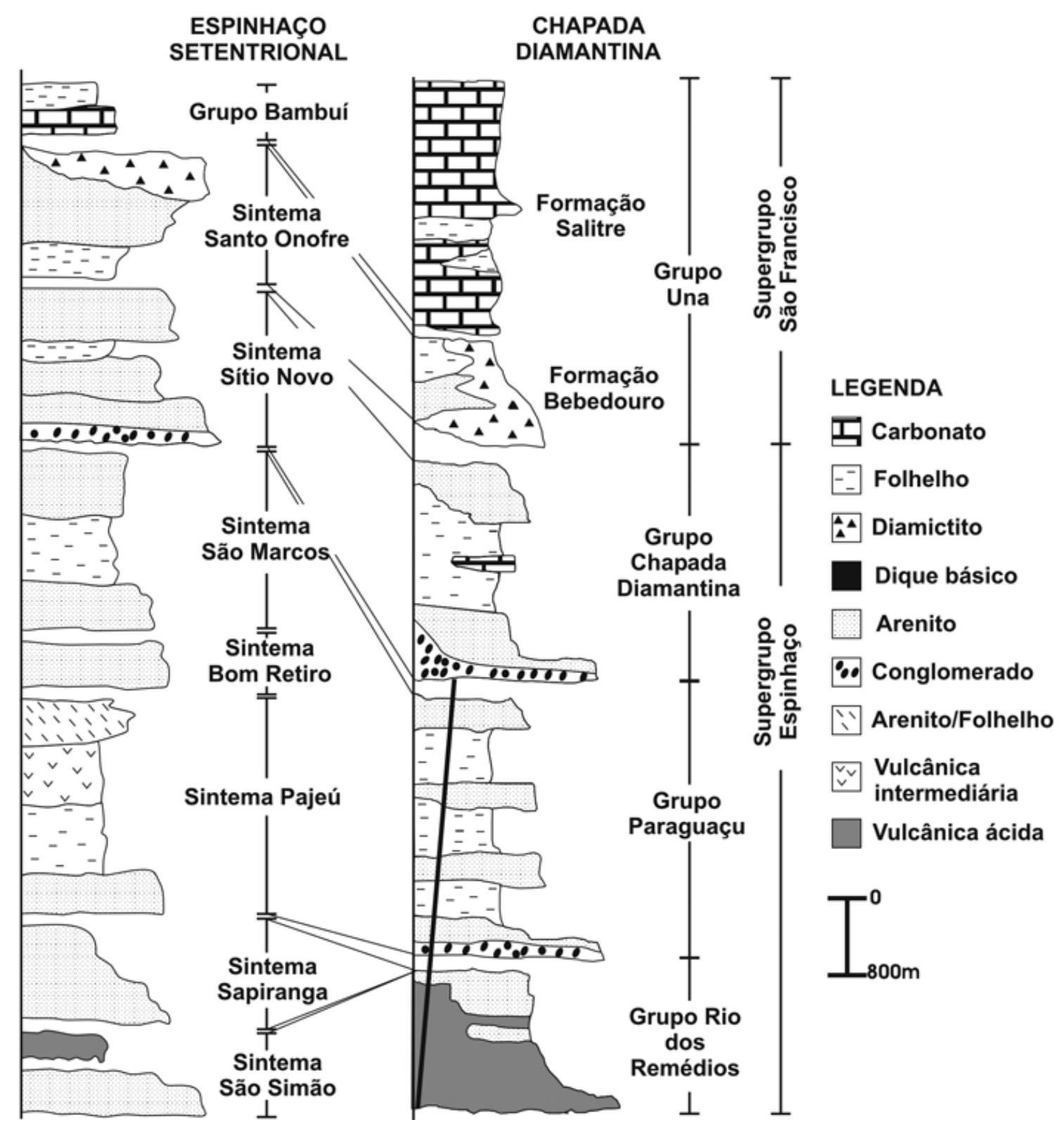

Figura 2 - Coluna Estratigráfica para os supergrupos Espinhaço e São Francisco no Aulacógeno do Paramirim, confecionada a partir de Danderfer $F^{\circ}$ (2000).

A terceira fase corresponde a um conjunto de estruturas com vergência para sul e que são encontradas no extremo norte da Chapada Diamantina, na Sinclinal de Irecê (Lagoeiro 1990).

Diversos são os modelos aventados para explicar a inversão do Aulacógeno do Paramirim e as principais controvérsias são a cerca da idade dessa inversão e do mecanismo focal que a teria gerado. Nesse contexto, pode ser citado o modelo verticalista de Jardim-de-Sá et al. (1976), em que a instalação da bacia em questão estaria associada com o desenvolvimento de um domo termal-junção tríplice, aulacógeno-rifte, em ambiente intraplaca continental, como resposta de uma anomalia térmica no manto. Posteriormente, Moutinho da Costa \& Inda (1982) propuseram que a evolução do Aulacó- geno do Espinhaço seria marcada por uma alternância entre períodos de soerguimento e subsidência, acompanhados ou seguidos de deformação, metamorfismo e erosão de unidades já depositadas, durante o Meso e Neoproterozóico.

Em um cenário de discussão sobre a existência ou não do chamando Ciclo Espinhaço, no Mesoproterozóico, Schobbenhaus $(1993,1996)$ propuseram que o aulacógeno em questão tenha se desenvolvido a partir de duas tafrogêneses superpostas, seguidas de fases de subsidência flexural, e que a sua inversão teria ocorrido no Neoproterozóico. Por outro lado, em seus trabalhos na porção oriental da Chapada Diamantina, Pedreira (1994) identificou cinco ciclos de embaciamento entre o Meso e o Neoproterozóico e propôs que a sedimentação 
das unidades basais do Supergrupo Espinhaço remontaria ao final do Paleoproterozóico, estando associada com a formação de uma margem passiva. A deposição das unidades do Grupo Chapada Diamantina teria ocorrido em bacia de antepaís associada com as colisões que estruturam o cinturão Contendas Mirante-Jacobina.

Trompette et al. (1992) e Trompette (1994) caracterizaram uma Faixa Brasiliana do ParamirimQuadrilátero Ferrífero que seria gerada por deformação intracontinental decorrente do fechamento de um rifte intracratônico, a partir de colisões na borda do Cráton do São Francisco, no Neoproterozóico. Essa faixa separaria os crátons de Salvador e Paramirim, tal qual proposto por Cordani (1973). Alkmim et al. (1993), por sua vez, postularam que a inversão da porção sul do Aulacógeno teria sido desencadeada pela indentação do bloco do embasamento adjacente à faixa Araçuaí, no eixo do Aulacógeno. A movimentação em direção ao norte do Bloco do Paramirim daria origem a movimentos sinistrais a reversos sinistrais ao longo do Espinhaço Setentrional e destrais a reversos destrais ao longo da borda da Chapada Diamantina.

Por meio de correlações regionais, Danderfer Fo (2000) propôs um modelo de evolução para os supergrupos Espinhaço e São Francisco na região da Chapada Diamantina e do Espinhaço Setentrional. Esse modelo congrega sucessivos episódios de rifteamento e de subsidência flexural, que juntos, somam oito pulsos de formação de bacia, que teriam tido lugar em um intervalo de duração superior a $900 \mathrm{Ma}$. Esse autor reconhece um único evento deformacional absorvido igualmente pelas rochas Espinhaço e São Francisco na região da Chapada Diamantina e no Espinhaço Setentrional. Somente ao sul do paralelo de $12^{\circ} 45^{\prime} \mathrm{S}$ é que o embasamento estaria envolvido na deformação da cobertura. Ao norte desse paralelo, as unidades sedimentares estariam em sua posição original.

Recentemente, Cruz (2004) subdividiu o Aulacógeno do Paramirim em dois segmentos tectônicos distintos. O segmento norte, que se estende desde a região próxima ao limite entre os estados da Bahia e do Piauí até as proximidades da cidade de Boquira (BA), abriga a zona de interferência entre o Aulacógeno do Paramirim e a Faixa de Dobramentos Rio Preto, bem como suas porções praticamente não invertidas. No segmento sul, da cidade de Boquira (BA) até o limite Bahia-Minas Gerais, as estruturas distensionais da formação desse aulacógeno são progressivamente invertidas. A inversão do Aulacógeno do Paramirim se deu por intermédio da nucleação de zonas de cisalhamento que mostram uma história de sucessivas reativações. As estruturas mais antigas, com orientação WSW-ENE, marcam a interação desse aulacógeno com o cinturão de cavalgamentos e dobramentos Araçuaí-Oeste Congo disposto ortogonalmente a ele. A fase seguinte nucleia estruturas NNW/ SSE e marca a inversão frontal do Aulacógeno, cujo mecanismo focal localiza-se na Faixa Brasília. Os elementos estruturais previamente nucleados são rotacionados e a curvatura é amplificada, num processo semelhante ao previsto na formação de oroclines.
As estruturas deformacionais identificadas na porção sul do Aulacógeno do Paramirim por Cruz (2004) podem ser encontradas no embasamento, no Complexo Lagoa Real e nas rochas metassedimentares dos supergrupos Espinhaço e São Francisco, levando Alkmim (2004) a incluir essa região no domínio da Faixa Araçuaí-Oeste Congo.

\section{PRINCIPAIS TRACOS DA GEOLOGIA DA SIN-} CLINAL DE ITUAÇU A Sinclinal de Ituaçu é uma sinforme aberta, com comprimento de onda de, aproximadamente, $50 \mathrm{~km}$ e traço axial orientado segundo NNW-SSE. Dela participam o embasamento, as rochas do Complexo Lagoa Real e as rochas metassedimentares dos supergrupos Espinhaço e São Francisco.

Segundo Menezes Fo (1996), como unidades de cobertura discriminam-se, no âmbito do sinclinal, uma série de unidades litoestratigráficas cujo conteúdo não encontra correspondência integral com as unidades tradicionalmente atribuídas ao Supergrupo Espinhaço na região norte do paralelo $13^{\circ} 00^{\prime} \mathrm{S}$ e que estão listadas na figura 2. Em função disso, esse autor utilizou denominações informais para agrupar as unidades que compõem o Supergrupo Espinhaço na Sinclinal de Ituaçu. Tendo em vista que a base geológica utilizada para a realização do mapeamento estrutural na Sinclinal de Ituaçu foi o mapa produzido por Menezes Fo (1996), sua nomenclatura será aqui mantida. Adota-se, assim, a subdivisão estratigráfica proposta por esse autor, que é reproduzida na figura 3.

O Supergrupo São Francisco está representado na porção central da Sinclinal de Ituaçu pelas formações Bebedouro e Salitre. A Formação Bebedouro compreende um conjunto de diamictitos maciços a grosseiramente estratificados, ritmitos finamente laminados e ardósias, que sugerem deposição por fluxo de detritos em plataforma marinha rasa sob influência glacial (Guimarães 1996). A Formação Salitre é constituída por uma seqüência de calssilutitos laminados, calcarenitos, argilitos carbonáticos, margas, dolomitos, que se encontra em contato transicional com as rochas da Formação Bebedouro (Menezes $\mathrm{F}^{\circ}$ 1996). A deposição dessas rochas se deu em rampa instalada sobre uma topografia com baixo declive, herdado de uma plataforma siliciclástica antecedente (Leão et al. 1992, Menezes Fo 1996).

\section{ARCABOUÇO ESTRUTURAL DA SINCLINAL}

DE ITUAÇU Delineado pelos contatos entre as grandes unidades envolvidas e pela superfície de acamamento das mesmas, a Sinclinal de Ituaçu (Figs. 4 e 5) apresenta-se como uma dobra regional com duplo caimento. Na figura 6a tem-se o diagrama estereográfico sinóptico dos pólos do acamamento das rochas dos supergrupos Espinhaço e São Francisco. Observa-se nele um grande espalhamento dos pólos em torno de um máximo principal sugere uma dobra acilíndrica.

$\mathrm{Na}$ Sinclinal de Ituaçu foram reconhecidas duas famílias de estruturas compressionais, aqui designadas $\mathrm{D}_{\mathrm{a}}$ e $\mathrm{D}_{\mathrm{p}}$. A fase $\mathrm{D}_{\mathrm{a}}$ é caracterizada pelo desenvolvimento de zonas de cisalhamento, com foliação milonítica 


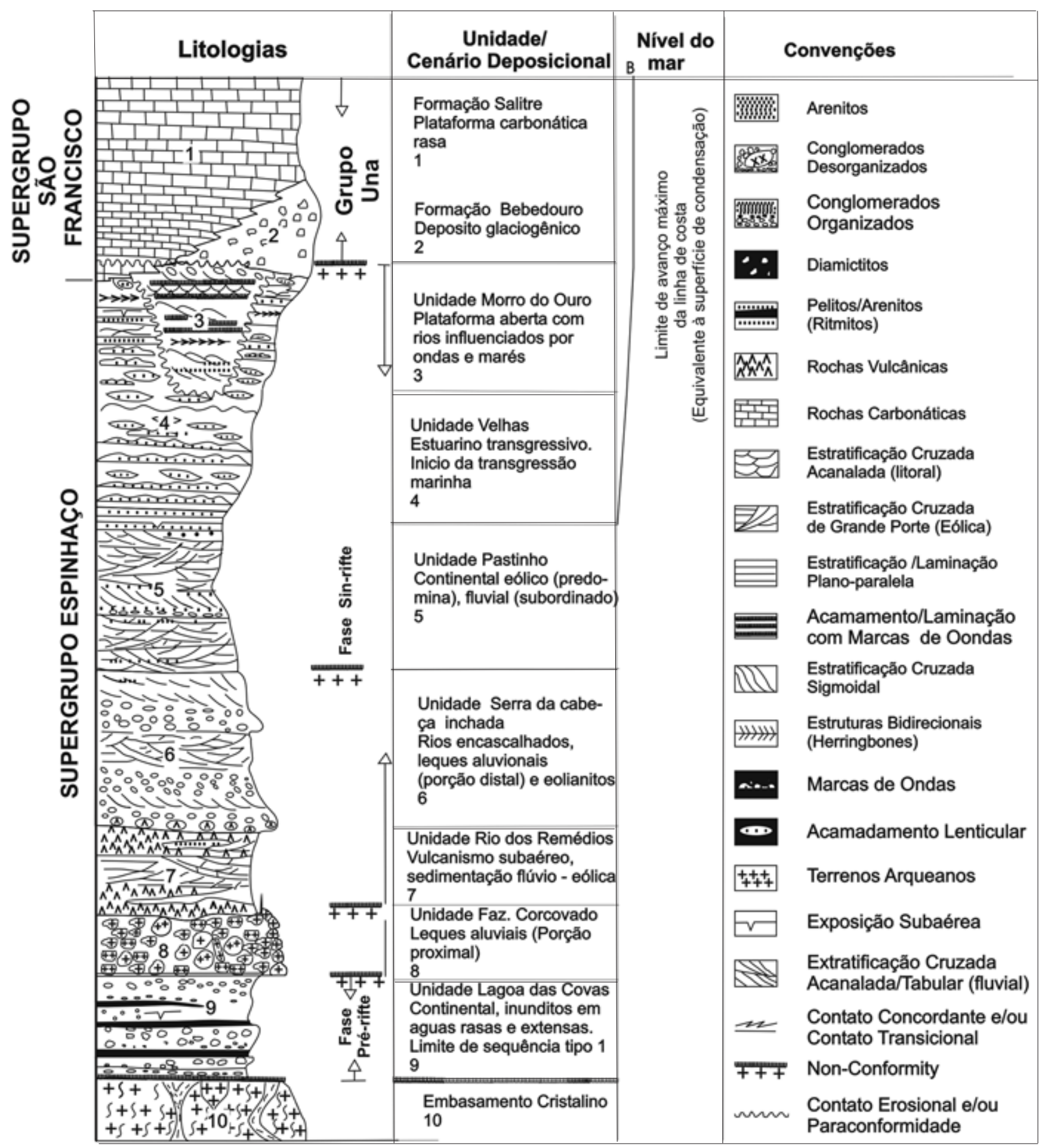

Figura 3 - Coluna estratigráfica proposta por Menezes Fo (1996) para o Supergrupo Espinhaço e São Francisco na Sinclinal de Ituaçu.

e lineação de estiramento mineral segundo 205/15 e 202/20, respectivamente (Figs. 6b, 6c), leques imbricados e trens de dobras, com orientação geral WNW-ESE (Fig. 6d) e vergência para NNE (Fig. 7). Essa fase é penetrativa na porção sul da sinclinal em questão. Regionalmente, pode ser encontrada no embasamento ao sul do paralelo de $14^{\circ} 00^{\prime} \mathrm{S}$.

Os elementos estruturais da fase seguinte, $\mathrm{D}_{\mathrm{p}}$, truncam aqueles previamente nucleados. Durante a fase $D_{p}$ formaram-se zonas de cisalhamento e dobras
(Fig. 8). As zonas de cisalhamento apresentam-se segundo NNW-SSE (Fig. 6e). A lineação de estiramento associada a essa fase é amplamente variável, desde alta a até baixa obliqüidade (Fig. 6f). As lineações de baixa obliqüidade predominam na zona de cisalhamento João Correia-Barra do Mendes. À medida que se adentra o sinclinal, em direção ao leste, as lineações são, preferencialmente, de alta obliqüidade. As dobras apresentam-se abertas, variando entre simétricas e assimétricas (nesse caso, a vergência é para ENE) e com 

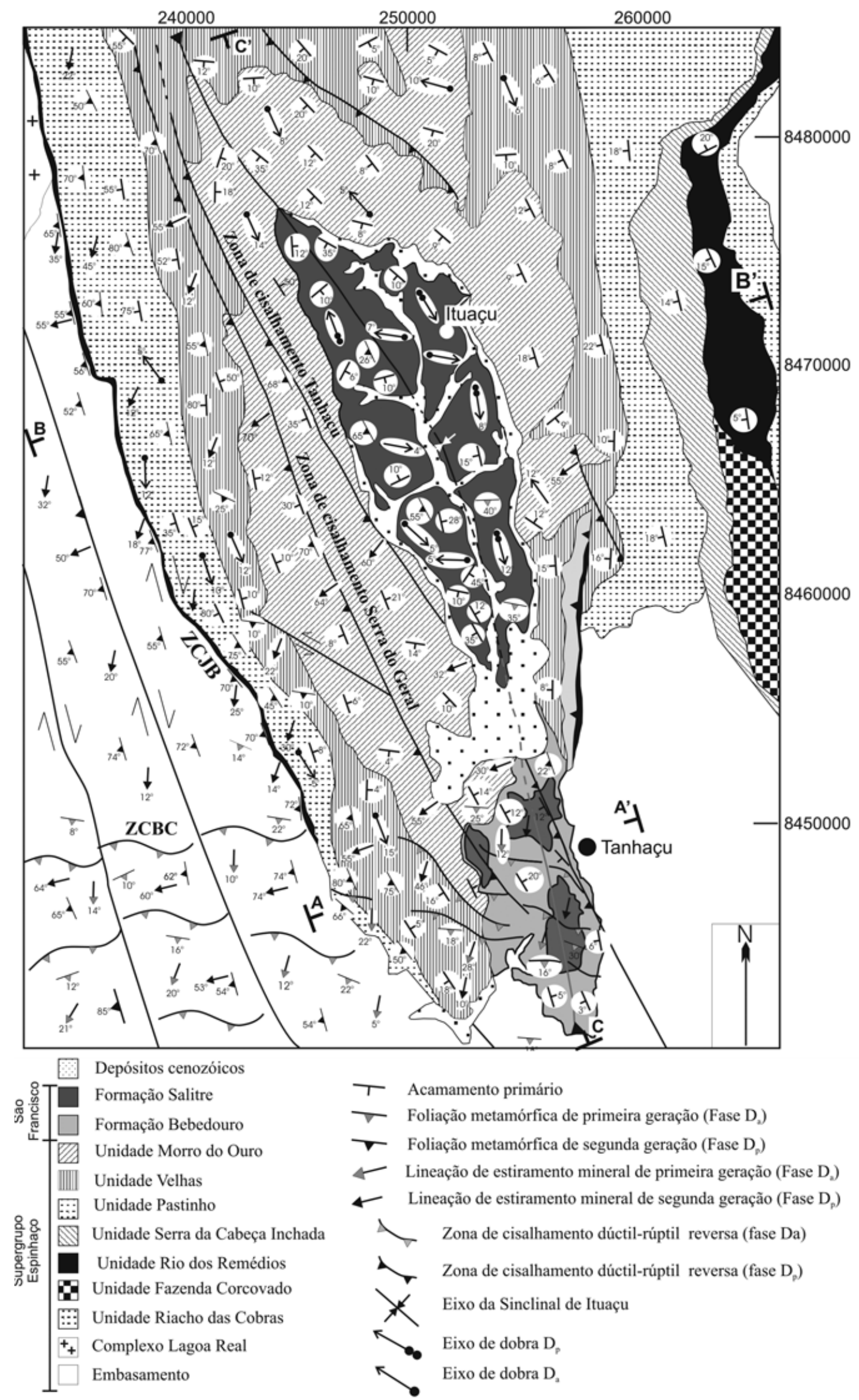

Figura 4 - Mapa geológico da Sinclinal de Ituaçu. Os perfis $A-A$ ', $B$-B' e $C$-C' estão apresentados na Figura 5. ZCBC-Zona de cisalhamento Brumado-Caetité, ZCJB-Zona de cisalhamento João Correia-Barra do Mendes. 


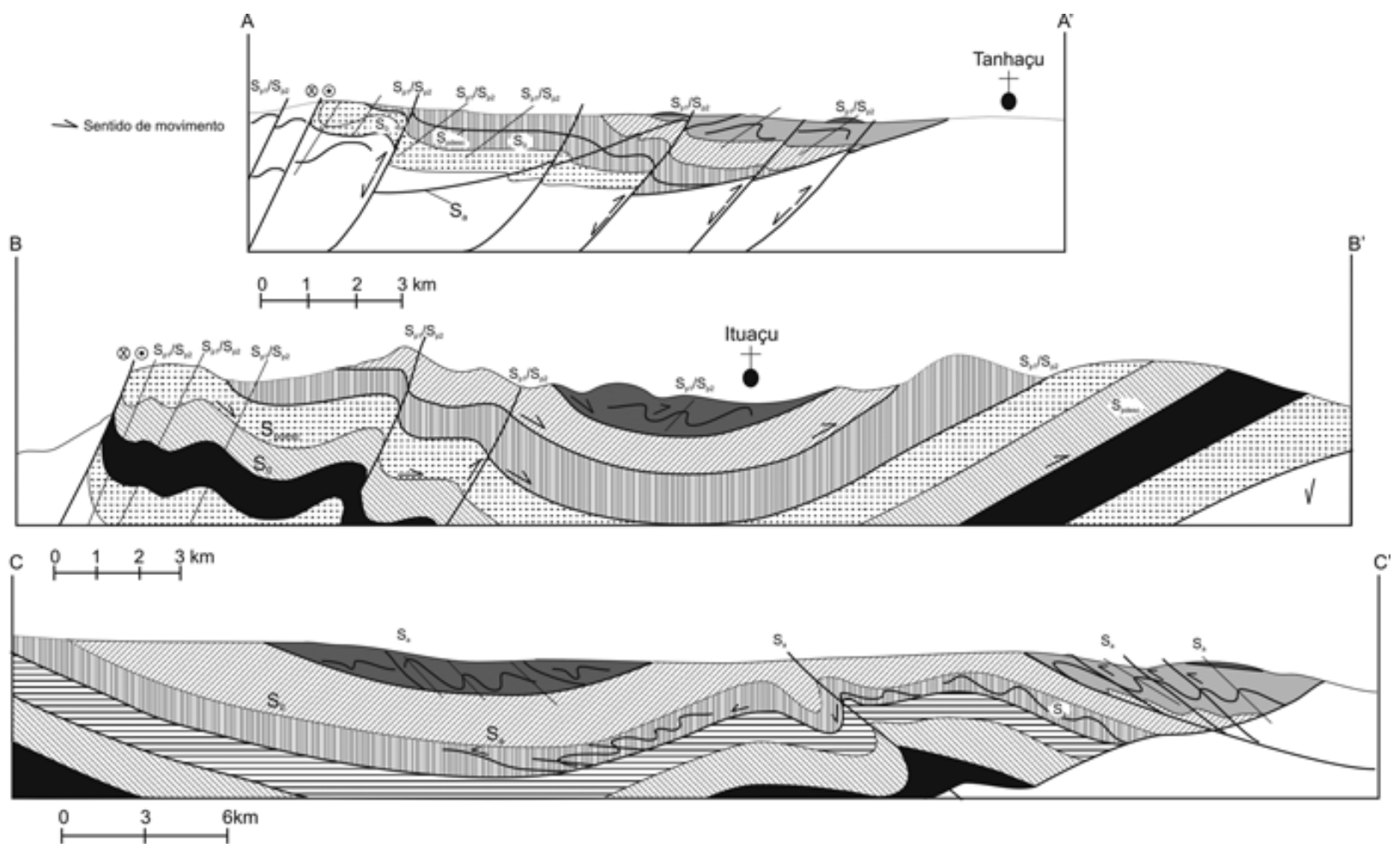

Figura 5 - Perfis geológicos transversalmente $\left(A-A^{\prime}-B-B^{\prime}\right)$ e ao longo (C-C') à Sinclinal de Ituaçu. A posição dos perfis encontra-se marcada na Figura 4. A legenda de litologias é igual à daquela figura e a escala vertical está exagerada 3 vezes.

linhas de charneiras posicionando-se em 166/03 (Fig. $6 \mathrm{~g})$.

O desenvolvimento da fase de $\mathrm{D}_{\mathrm{p}}$ comporta três estágios. Numa etapa precoce, $\mathrm{D}_{\text {pdesc }}$, formaram-se zonas de cisalhamento cegas, inter e intraestratais. Essas zonas foram sucedidas por um conjunto de megadobras abertas que afetam as zonas de cisalhamento pré-existentes. Todas essas estruturas foram nucleadas acima da interface embasamento-cobertura. $\mathrm{Na}$ fase final do encurtamento, etapas $\mathrm{D}_{\mathrm{p} 1}$ e $\mathrm{D}_{\mathrm{p} 2}$, zonas de cisalhamento com médio a alto ângulo de mergulho foram nucleadas e truncaram todo o conjunto de estruturas anteriormente nucleado. Essas estruturas, em conjunto, compõem o sistema de empurrões e dobramentos da Chapada Diamantina, cuja nucleação marca a fase de envolvimento do embasamento na deformação da cobertura.

O arcabouço estrutural da Sinclinal de Ituaçu relaciona-se com superfícies de cisalhamento profundas que marcam a ascensão do embasamento sobre as rochas metassedimentares da Chapada Diamantina. Dessa forma, a sua estruturação deve-se, sobretudo, aos estágios $\mathrm{D}_{\mathrm{p} 1}$ e $\mathrm{D}_{\mathrm{p} 2}$.

$\mathrm{Na}$ figura 9 tem-se o mapa de domínio estrutural da Sinclinal de Ituaçu. De uma maneira geral, a intensidade da deformação diminui de oeste para leste e de sul para norte. De acordo com a predominância e orientação das estruturas associadas às duas fases de deformação reconhecidas, a sinclinal em foco foi subdividida em três domínios estruturais (Fig. 9), descritos a seguir.
O contato oeste das unidades envolvidas na sinclinal com o embasamento se faz por meio da zona de cisalhamento João Correia-Barra do Mendes (Fig. 4). Trata-se de uma zona dúctil-rúptil com movimentação destral reversa e mergulho variando entre 60 e $80^{\circ}$ que coloca o embasamento sobre as rochas do Supergrupo Espinhaço. A sua nucleação está relacionada com a fase $\mathrm{D}_{\mathrm{p}}$. Os contatos leste e sudeste se fazem por intermédio de discordância angular e erosiva.

$\mathrm{O}$ contato entre as rochas dos supergrupos Espinhaço e São Francisco, na sinclinal em questão, é assinalado por uma proeminente discordância erosiva (Menezes Fo 1996). Em alguns locais, entretanto, aloja-se nesse contato uma superfície de descolamento, marcada pela ocorrência de milonitos. Essa superfície apresenta-se dobrada e com orientação variável; sua atitude modal é 206/14 (Fig. 6h). Sobre ela, é possível reconhecer uma lineação de sulcos e estrias de movimento, cuja orientação preferencial é 186/03 (Fig. 6i). Estruturas do tipo slickensides sugerem movimentos de SSW para NNE e de WSW para ENE. Devido ao dobramento posterior, pode apresentar caimentos para todos os quadrantes. A geometria deste contato e o espalhamento na distribuição das lineações está relacionado com a superposição das fases deformacionais $\mathrm{D}_{\mathrm{a}}$ e $\mathrm{D}_{\mathrm{p}}$, conferindo um padrão de interferência do tipo "Domos e Bacias".

Domínio Estrutural I O Domínio I compreende a porção sudoeste da sinclinal (Fig. 9), área de aflora- 


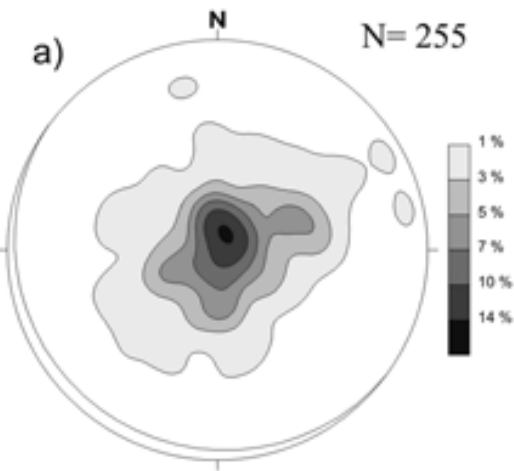

Acamamento - $\mathrm{S}_{0}$

Supergrupos Espinhaço e Săo Francisco Sinclinal de Ituaçu

Máximo: 216/07

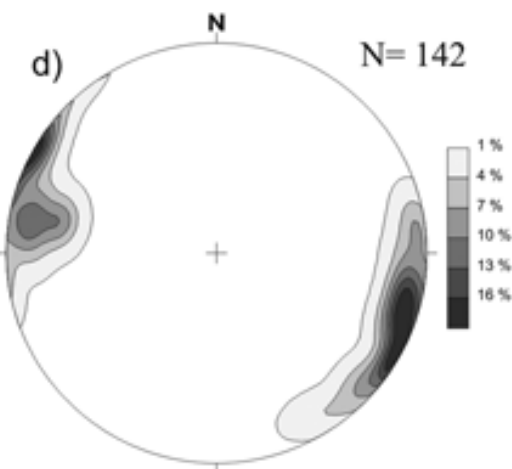

Linha de charneiras de dobras - Lb, Supergrupos Espinhaço e São Francisco Sinclinal de Ituaçu Máximo: 107/07

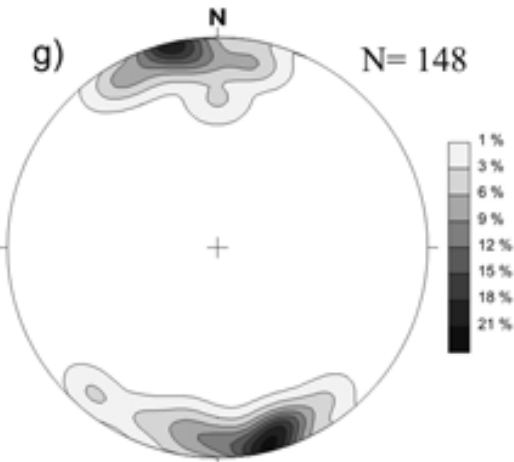

Linha de charneiras de dobras - L $b_{\text {o }}$ Supergrupos Espinhaço e SăoFrancisco Sinclinal de Ituaçu Máximo: 166/03 b)

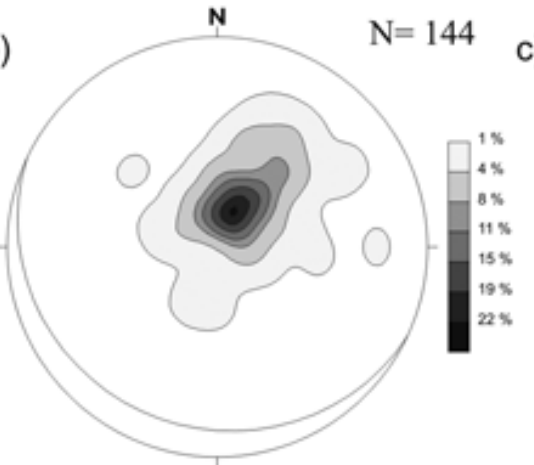

Foliaçăo milonítica - $\mathrm{S}$, Supergrupos Espinhaço e São Francisco Sinclinal de Ituaçu Máximo: 205/15

e)

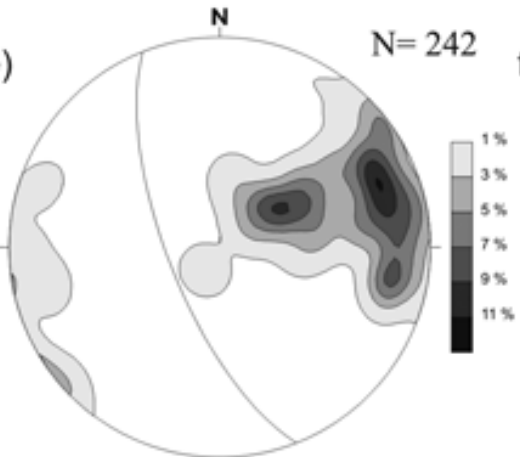

Foliaçăo milonítica - $S_{p}$ Supergrupos Espinhaço e São Francisco Sinclinal de Ituaçu Máximo: $249 / 70$

h)

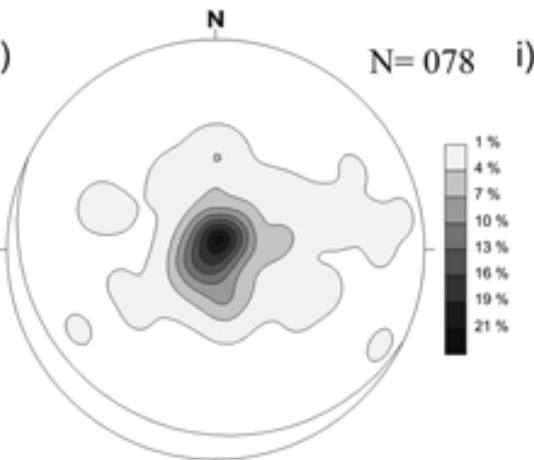

Foliaçăo milonítica - $\mathrm{S}$ Descolamento Basal Supergrupos Espinhaço e São Francisco Supergrupos Espinhaço e Săo Francisco Sinclinal de Ituaçu Máximo: 206/14

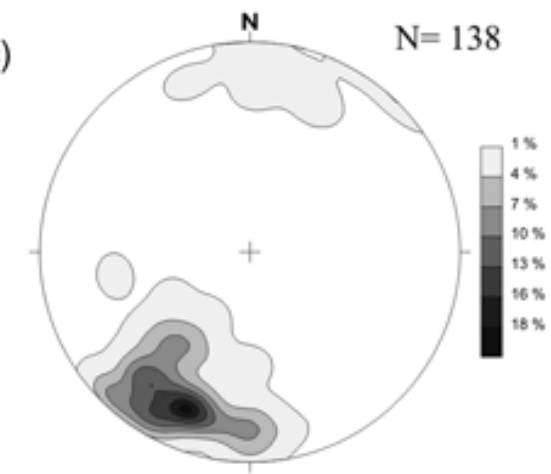

Lineação de estiramento - Lx, Supergrupos Espinhaço e São Francisco Sinclinal de Ituaçu Máximo: 202/20 $\mathrm{N}$

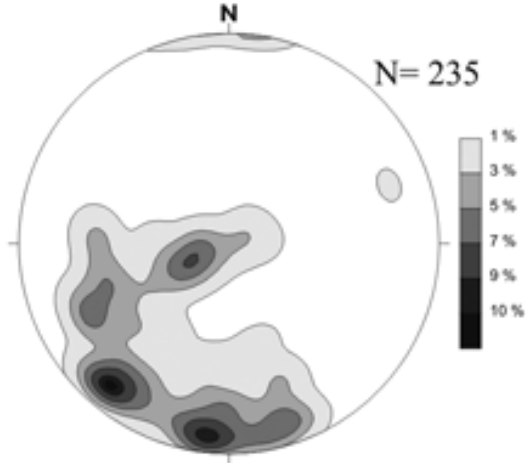

Lineação de estiramento - Lx Supergrupos Espinhaço e São Francisco Sinclinal de Ituaçu Máximo: 220/13

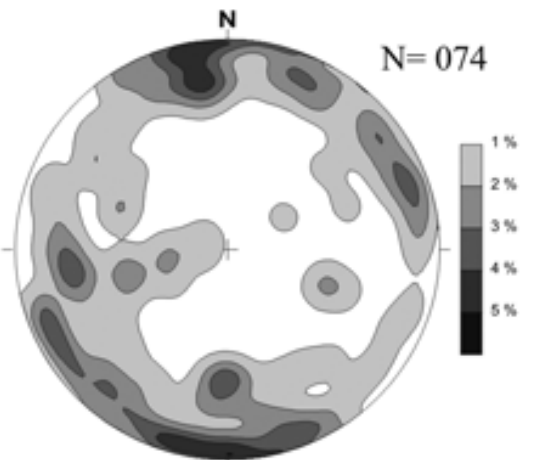

Lineaçăo de estiramento - $L x_{\text {pome }}$ Descolamento Basa

Sinclinal de Ituaçu Máximo: 180/03

Figura 6 - Diagramas estereográficos sinópticos (Hemisfério inferior) dos pólos do acamamento primário das unidades de cobertura da Sinclinal de Ituaçu, da foliação metamórfica e da lineação de estiramento das fases $D_{a}$ e $D_{p}$. N-Número de Amostras.

mento do embasamento, de parte da Unidade Velhas do Supergrupo Espinhaço e das formações Bebedouro e Salitre, do Supergrupo São Francisco (Fig. 4). Nesse domínio, existe uma forte similaridade entre os acervos estruturais das rochas dos supergrupos Espinhaço e São
Francisco. A diferença entre eles está no ângulo de mergulho das estruturas, que no caso do Supergrupo Espinhaço, é mais acentuado.

Podem ser encontradas estruturas associadas às fases $\mathrm{D}_{\mathrm{a}}$ e $\mathrm{D}_{\mathrm{p}}$. As relações de truncamento entre elas es- 


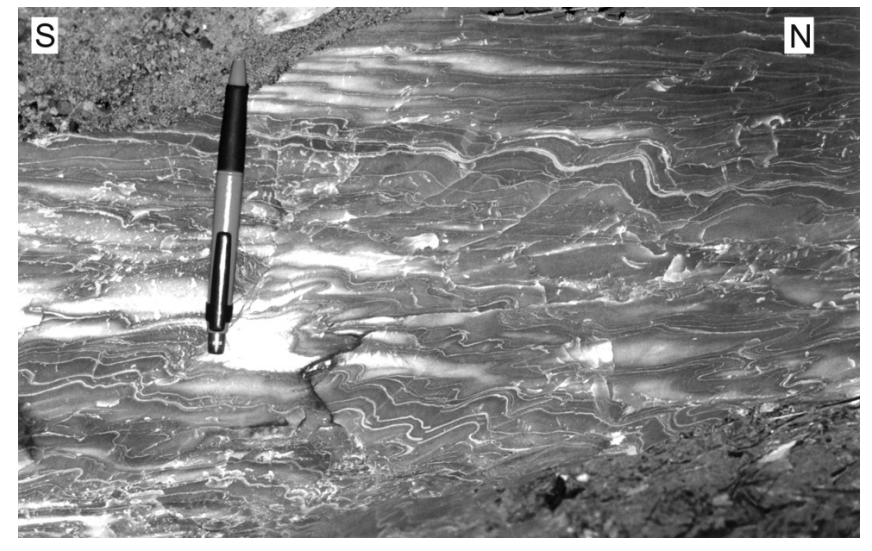

Figura 7 - Dobras assimétricas da fase $D_{a}$ em dolomitos da Formação Salitre, no núcleo da Sinclinal de Ituaçu. Corte em perfil.

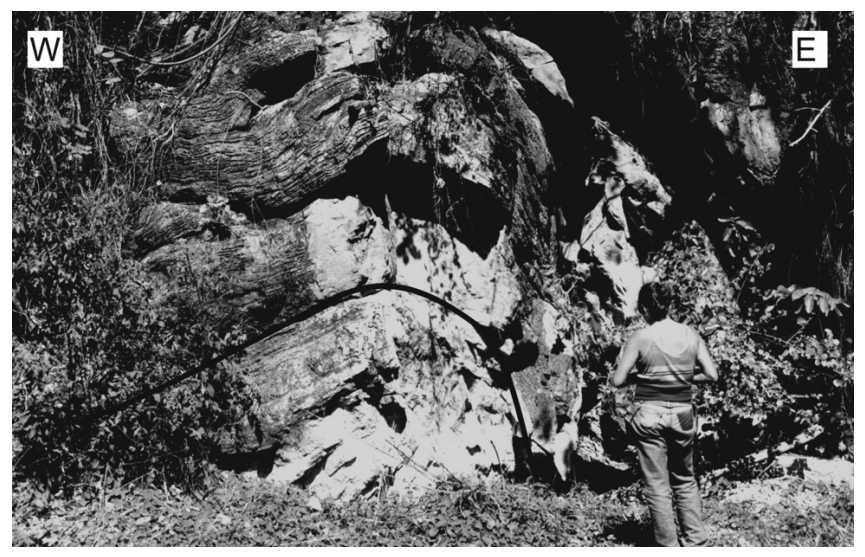

Figura 8 - Dobras assimétricas Dp em dolomitos da Formação Salitre (Domínio III). Corte, aproximadamente, em perfil.

tão muito bem expostas na região a sudoeste da cidade de Tanhaçu. Elementos da fase $\mathrm{D}_{\mathrm{a}}$ encontram-se obliterados pelas estruturas mais jovens, $\mathrm{D}_{\mathrm{p}}$ (Figs. 4, 5, perfis A-A' e C-C'). Em várias exposições, é possível observar, tanto no embasamento quanto na cobertura, que a foliação de baixo ângulo $S_{a}$ encontra-se truncada por uma série de zonas de cisalhamento de médio ângulo.

No embasamento do Domínio I, durante a fase $\mathrm{D}_{\mathrm{a}}$, nuclearam-se uma superfície milonítica e um bandamento metamórfico com orientação principal segundo 211/22 (Fig. 10a). O bandamento é marcado pela alternância de níveis ricos em biotita e hornblenda e bandas quartzo-feldspáticas. Essas estruturas materializam a zona de cisalhamento Brumado-Caetité, de natureza rúptil-dúctil (Fig. 4). Sobre a foliação principal desenvolveu-se uma lineação de estiramento marcada por cristais recristalizados de plagioclásio e quartzo, além de actinolita e biotita, posicionada em 202/22 (Fig. 10b). Indicadores cinemáticos observados nos tectonitos da zona de cisalhamento Brumado-Caetité sugerem movimento de SSW para NNE.

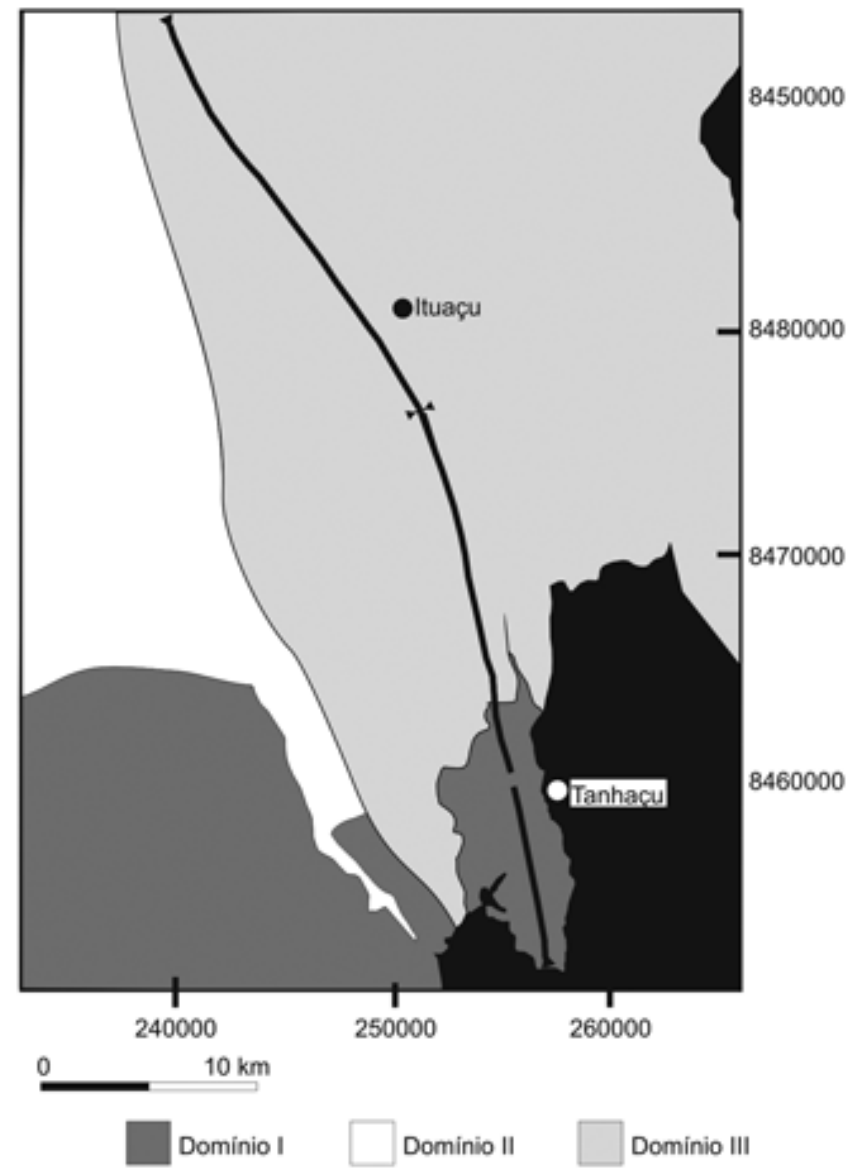

Figura 9 - Domínios estruturais na Sinclinal de Ituaçu, baseado na figura 4. A faixa em preto representa a porção onde as deformações $D_{p}$ são fracamente desenvolvidas.

Na Unidade Velhas e na Formação Bebedouro, formaram-se zonas de cisalhamento, também durante a fase $\mathrm{D}_{\text {. }}$ Entretanto, nesse caso, são de natureza dúctilrúptil. Nas unidades com granulação mais grossa, essas zonas se estruturam segundo um arranjo em leques imbricados que em profundidade devem se conectar com a zona de cisalhamento Brumado-Caetité.

$\mathrm{Na}$ Unidade Velhas, as zonas de cisalhamento possuem a atitude modal 196/35 e a lineação de estiramento está posicionada em 198/35 (Figs. 10c,d). Nessas rochas, as zonas de cisalhamento são estreitas e pouco desenvolvidas. A deformação $\mathrm{D}$ é acomodada, principalmente, por meio de dobras abertas que se associam a uma foliação plano axial, cuja atitude é 220/32 (Fig. 11a). Tais dobras possuem as charneiras orientadas segundo 280/08 (Fig. 11b). Na Formação Bebedouro, zonas de cisalhamento encontram-se amplamente desenvolvidas, com larguras de até 500 metros. Apresentam foliação penetrativa e lineação de estiramento com orientações preferenciais em 217/24 e 212/23, respectivamente (Fig. 10e, f). Fora das zonas de cisalhamento, pode ser encontrada uma foliação de baixo ângulo com direção WNW-ESE e mergulho para WSW (Fig. 11c). Essa foliação está associada às dobras que variam des- 


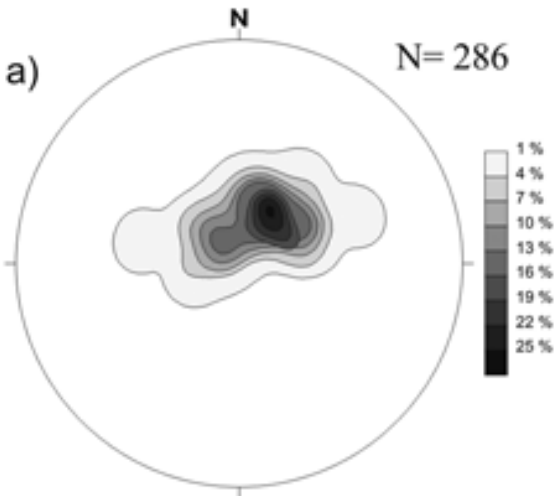

Foliaçăo milonítica - $\mathrm{S}$, Embasamento

Zonas de cisalhamento

Sinclinal de Ituaçu Domínio I

Máximo: 211/22

d)

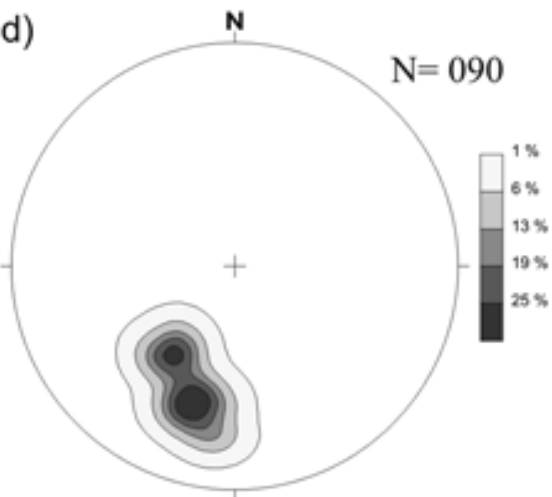

Lineação de estiramento - $L x_{a}$ Unidade Velhas

S. G. Espinhaço

Zonas de cisalhamento

Sinclinal de Ituaçu

Domínio I

Máximo: 198/35

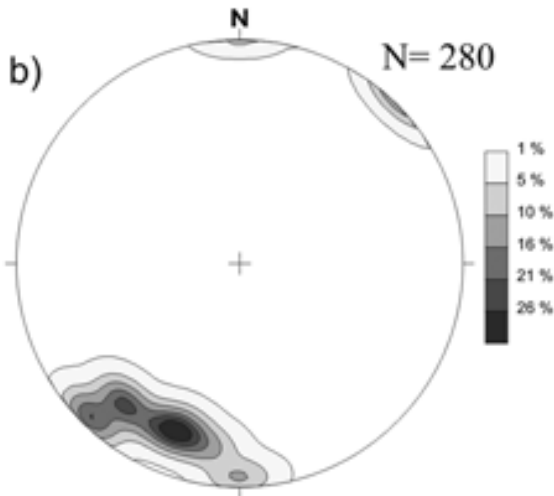

Lineaçăo de estiramento - $L x$ a Embasamento

Zonas de cisalhamento

Sinclinal de Ituaçu

Domínio I

Máximo: 202/22

e)

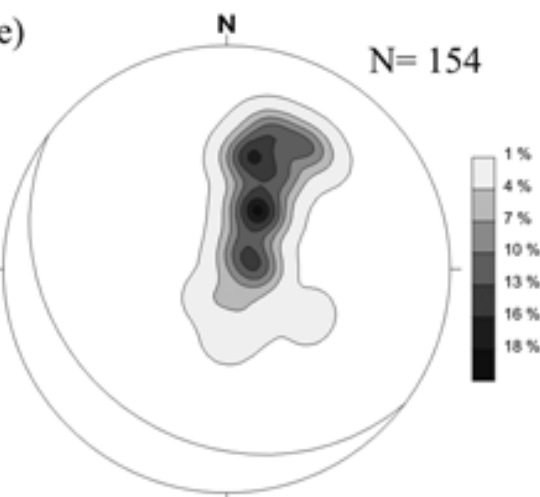

Foliação milonítica - $\mathrm{S}$, Formação Bebedouro S. G. São Francisco Zonas de cisalhamento Sinclinal de Ituaçu

Dominio I Máximo: 217/24

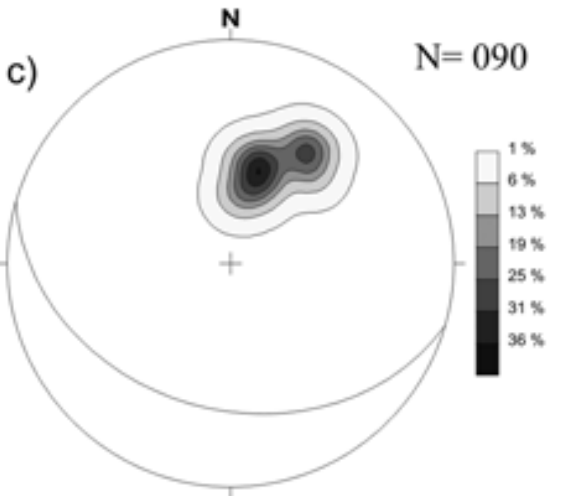

Foliação milonítica - $\mathrm{S}$, Unidade Velhas - S.G.Espinhaço Zonas de cisalhamento Sinclinal de Ituaçu Domínio I

Máximo: 196/35

f)

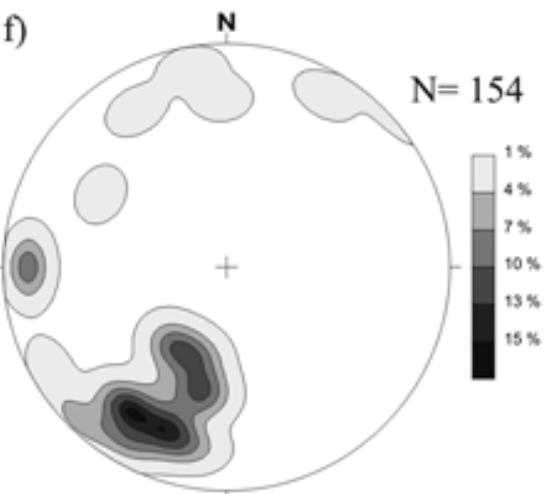

Lineação de estiramento - Lx, Formação Bebedouro

S. G. São Francisco

Zonas de cisalhamento

Sinclinal de Ituaçu Domínio I

Máximos: 212/23 // 202/23

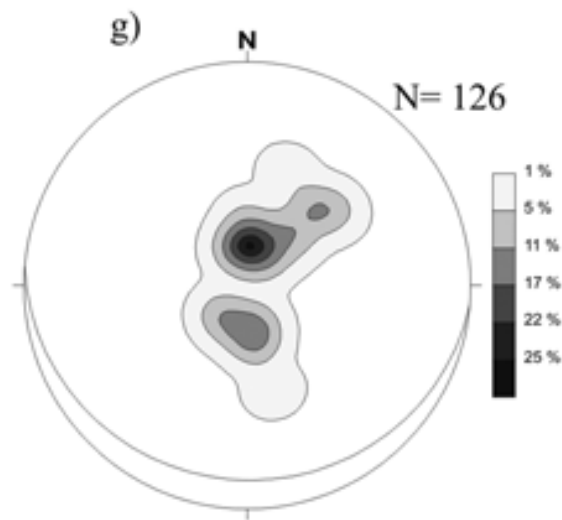

Foliaçăo milonitica - $\mathrm{S}_{\mathrm{a}}$

Formação Salitre

S. G. São Francisco

Zonas de cisalhamento

Sinclinal de Ituaçu

Domínio I

Máximo: 185/14

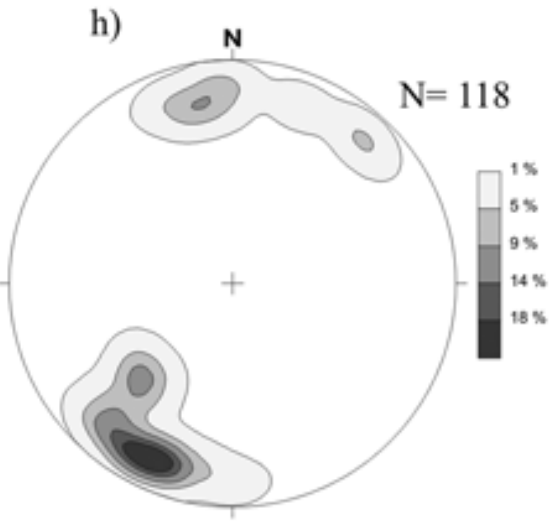

Lineação de estiramento - Lx,

Formação Salitre

S. G. São Francisco

Zonas de cisalhamento

Sinclinal de Ituaçu

Domínio I

Máximo: 207/15

Figura 10 - Diagramas estereográficos sinópticos (Hemisfério inferior) dos pólos da foliação e da lineação de estiramento $D_{a}$ nucleadas no embasamento e nas unidades de cobertura presentes no Domínio I. 
a)

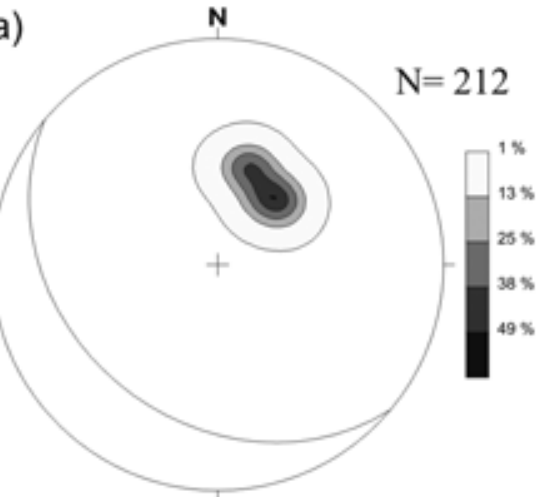

Foliação plano axial - S, Unidade Velhas S.G. Espinhaço Sinclinal de Ituaçu Domínio I Máximo: 220/32

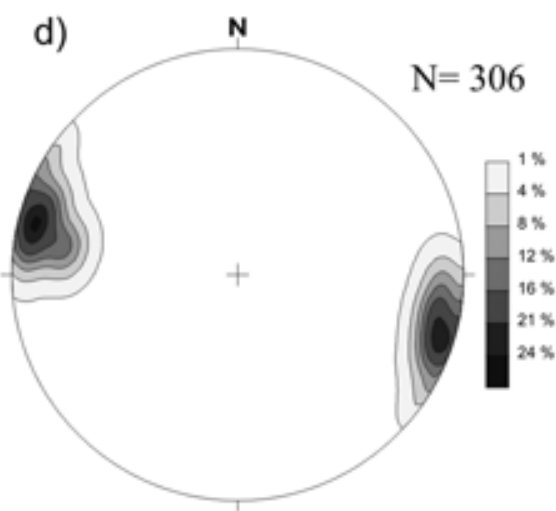

Linha de charneiras de dobras - Lb, Formação Bebedouro S. G. Săo Francisco Sinclinal de Ituaçu Domínio I Máximo: 284/10

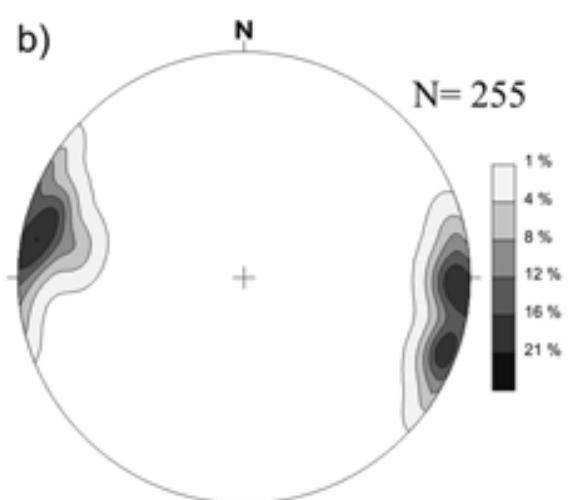

Linha de charneiras de dobras - Lb. Unidade Velhas - S.G. Espinhaço Sinclinal de Ituaçu Domínio I Máximo: $280 / 08$

e)

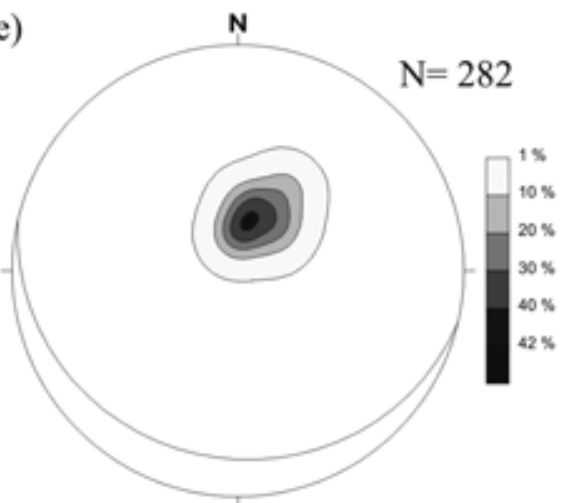

Foliação plano axial - S, Formação Salitre S.G. Săo Francisco Sinclinal de Ituaçu Domínio I Máximo: 193/18

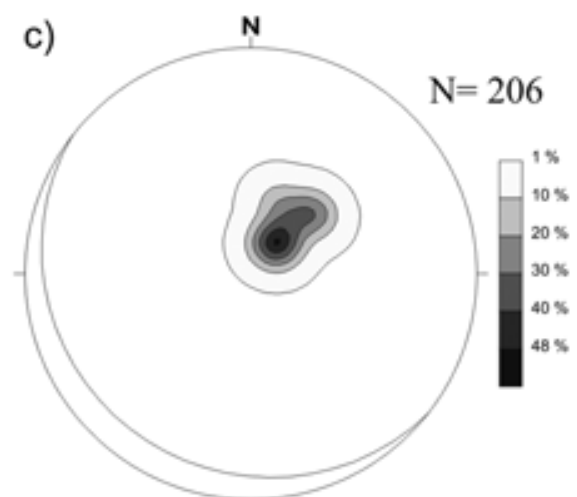

Foliação milonitica - $\mathrm{S}_{\text {a }}$ Formação Bebedouro S.G. São Francisco Sinclinal de Ituaçu Domínio I

Máximo: 218/14

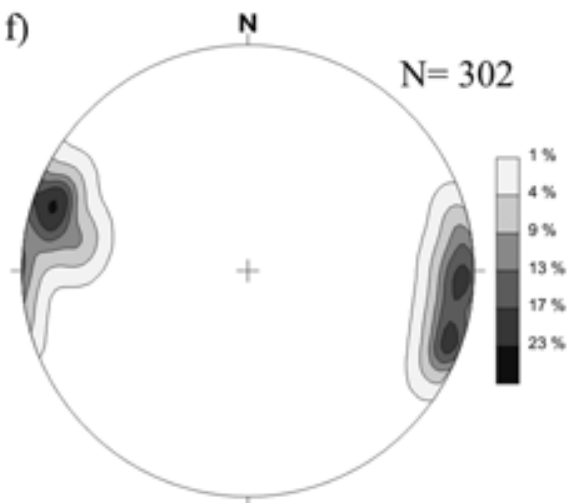

Linha de charneiras de dobras - Lb, Formação Salitre S.G. Săo Francisco Sinclinal de Ituaçu Domínio I Máximo: 289/10

Figura 11 - Diagramas estereográficos sinópticos (Hemisfério inferior) dos pólos da foliação de plano axial e da linha de charneira das dobras $D_{a}$ nucleadas nas unidades de cobertura do Domínio I.

de apertadas até abertas e que se desenvolvem, preferencialmente, com orientação 284/10 (Fig. 11d).

Nos calcários e dolomitos da Formação Salitre, a fase $\mathrm{D}_{\mathrm{a}}$ é marcada por zonas de cisalhamento e, principalmente, pela presença de dobras apertadas e assimétricas, vergentes para NNE (Fig. 7). As zonas de cisalhamento posicionam-se em 185/14 (Fig. 10g), com lineação de estiramento mineral de alta obliqüidade e disposta em 207/15 (Fig. 10h). As dobras afetam o acamamento e são observadas, sobretudo, em escala de afloramento. Podem desenvolver uma clivagem planoaxial, cuja orientação preferencial é 193/18 (Fig. 11e). Suas charneiras, por sua vez, ficam na posição 289/10 (Fig. 11f). Associada às dobras da fase $\mathrm{D}_{\mathrm{a}}$ é possível identificar a presença de deslizamentos interestratais com desenvolvimento de lineação de estiramento. São evidenciadas por cristais de calcita que se alinham, preferencialmente, em 214/19. Subordinadamente, nos carbonatos da Formação Salitre, a fase $\mathrm{D}_{\mathrm{a}}$ é marcada pela presença de zonas de cisalhamento ancoradas no embasamento. Essas falhas morrem no interior de antiformais e associam à fault propagation folds.

No Domínio I, a fase $\mathrm{D}_{\mathrm{p}}$ subdivide-se nos estágios $\mathrm{D}_{\mathrm{pdesc}}, \mathrm{D}_{\mathrm{p} 1}$ e $\mathrm{D}_{\mathrm{p} 2}$. No embasamento, os registros das etapas $\mathrm{D}_{\mathrm{p} 1}$ e $\mathrm{D}_{\mathrm{p} 2}$ podem ser separados em função da natureza das estruturas e da assembléia mineralógica. Entretanto, na cobertura a separação entre esses dois estágios é impossível.

No embasamento, o estágio $\mathrm{D}_{\mathrm{p} 1}$ é representado por um conjunto de zonas de cisalhamento de médio a alto ângulo que, localmente, também atinge a cobertura. Elas são destral-reversas e apresentam orientação e lineação de estiramento segundo 255/79 e 190/12, respectivamente (Fig. 12a, b). Associadas a essas zo- 
a)

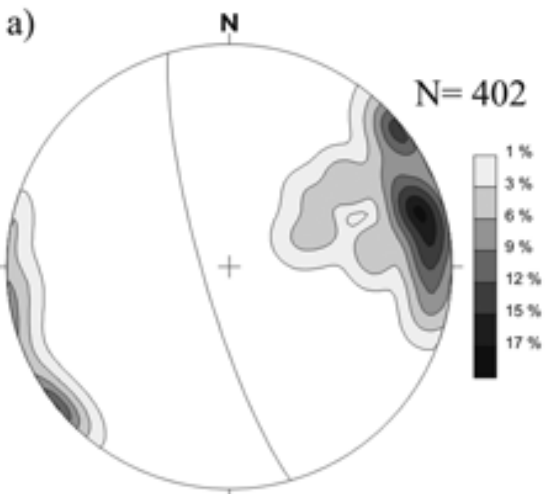
Foliação milonítica - $\mathrm{S}_{p}$ Embasamento Sinclinal de Ituaçu Dominio I Máximo: $255 / 79$

d)

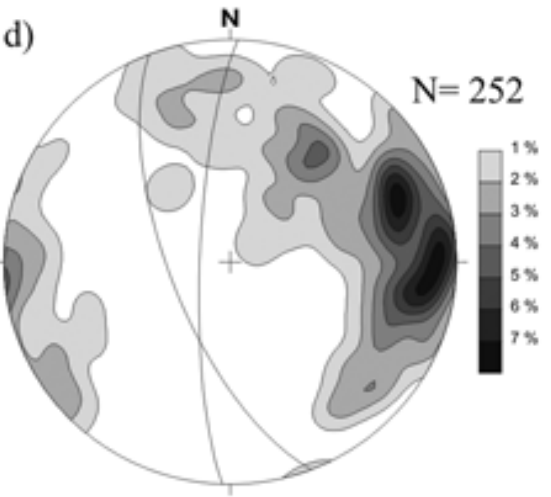

Foliação milonítica - $\mathrm{S}_{p 2}$ Embasamento

Zonas de cisalhamento Sinclinal de Ituaçu

Domínio I

Máximos: 249/68 // 272/79

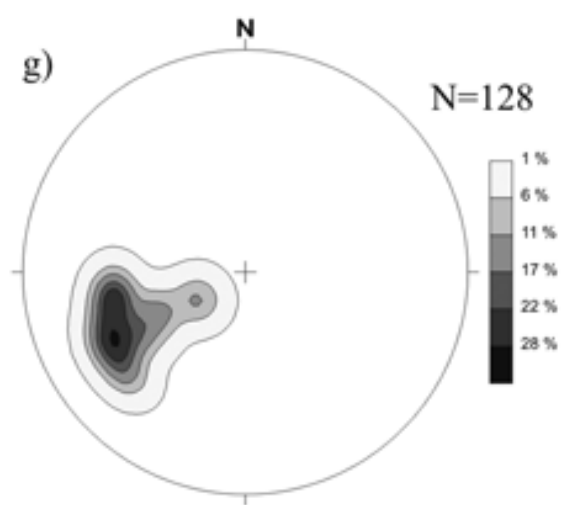

Lineação mineral - Lx, Cobertura Sedimentar Zonas de cisalhamento Sinclinal de Ituaçu Domínio Máximo: 243/35 b)

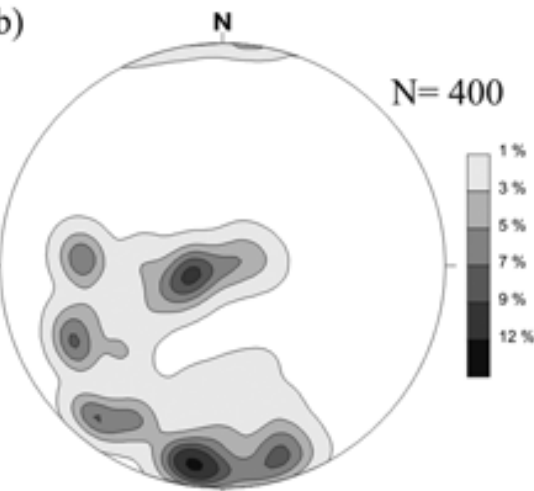

Lineação de estiramento - $L x_{p}$ Embasamento Sinclinal de Ituaçu

Dominio I

Máximo: 190/12

e)

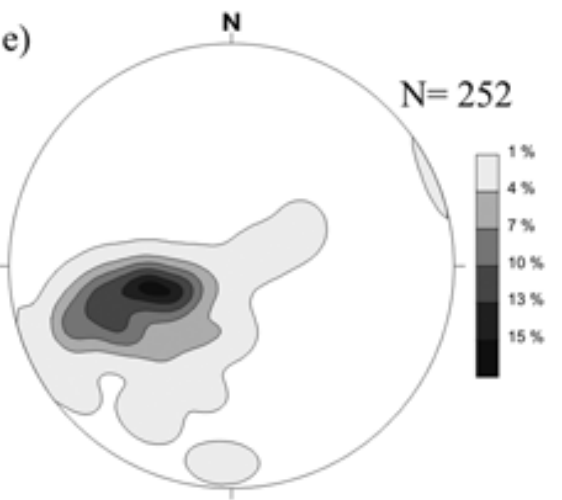

Lineação de estiramento - $L x_{p 2}$ Embasamento

Zonas de cisalhamento Sinclinal de Ituaçu Dominio 1

Máximo: 254/59

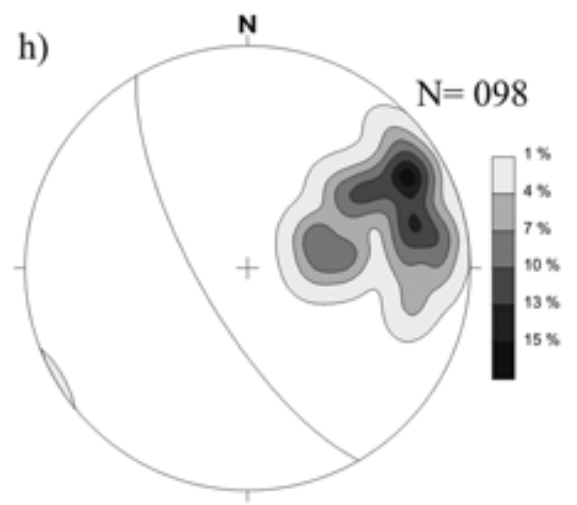

Foliação de plano axial - $S_{p}$ Cobertura Sedimentar Sinclinal de Ituaçu Domínio I

Máximo: 241/72

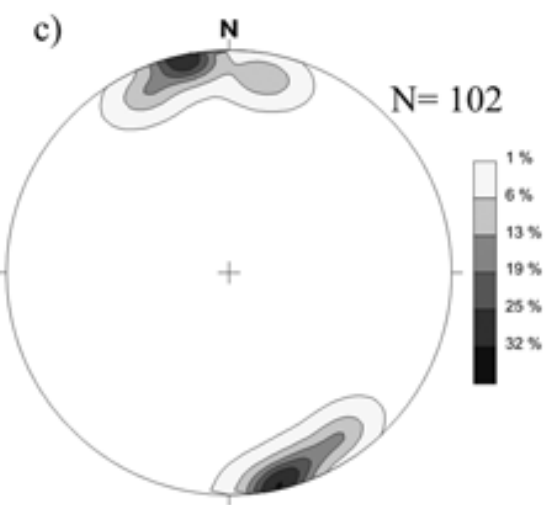

Charneiras de dobras - $D_{p 1}$ Embasamento Sinclinal de Ituaçu Dominio I Máximo: 167/02

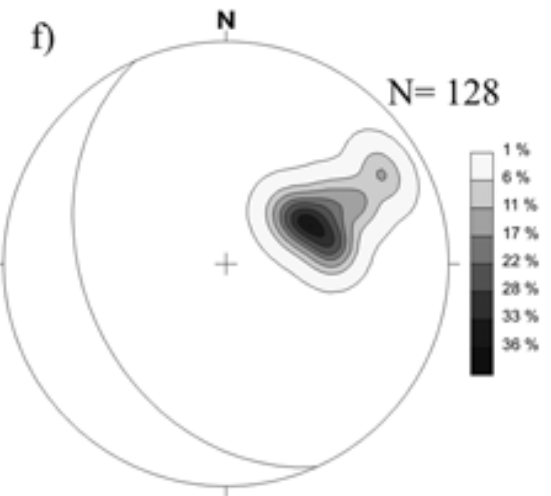

Foliação milonítica - $\mathrm{S}_{\mathrm{p}}$ Cobertura Sedimentar Zonas de cisalhamento Sinclinal de Ituaçu Domínio I Máximo: 246/36

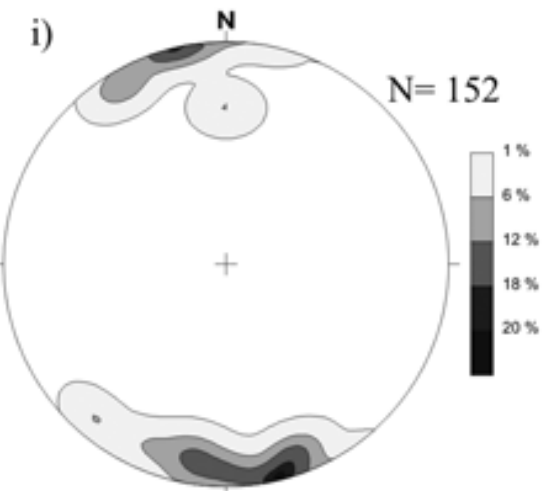

Linha de charneiras de dobras - Lb, Cobertura Sedimentar Sinclinal de Ituaçu Domínio I Máximo: 166/02

Figura 12 - Diagramas estereográficos sinópticos (Hemisfério inferior) das estruturas $D_{p}$ presentes no Domínio I.

nas de cisalhamento, têm-se dobras abertas a fechadas e horizontais que afetam a foliação $\mathrm{S}_{\mathrm{a}}$ e o bandamento gnáissico associado. Apresentam vergência para leste e charneiras orientadas preferencialmente na direção 
167/02 (Fig. 12c).

Durante o estágio $\mathrm{D}_{\mathrm{p} 2}$, fraturas e zonas de cisalhamento de alto ângulo formaram-se no embasamento. Sua atitude modal varia entre 249/68 e 272/79 (Fig. 12d) e apresentam lineação de estiramento cuja orientação preferencial é 254/59 (Fig. 12e). Estruturas S/C sugerem movimentos reversos associados com essas zonas.

Nas unidades de cobertura, as estruturas desenvolvidas durante o estágio $\mathrm{D}_{\text {pdesc }}$ foram bastante deformadas nas etapas seguintes. Entretanto, nos calcários que afloram no núcleo da Sinclinal de Ituaçu é possível encontrar dobras de várias ordens hierárquicas associadas a esse estágio de deformação. Nesse contexto, zonas de cisalhamento intraestratais e interestratais ocorrem, preferencialmente, nas unidades da Formação Salitre. Essas zonas apresentam foliação metamórfica com orientação preferencial de 246/36 e lineação de estiramento em 243/35 (Figs. 12f, g). Os movimentos são preferencialmente para ENE.

Zonas de cisalhamento de alto ângulo das etapas $\mathrm{D}_{\mathrm{p} 1}$ e $\mathrm{D}_{\mathrm{p} 2}$ ocorrem truncando todas as estruturas anteriormente nucleadas (Fig. 10). São rúpteis e provocam a rotação ou a transposição dos elementos estruturais mais antigos. Como essas estruturas apresentamse amplamente distribuídas no Domínio III, elas serão descritas na seção referente a esse domínio. As dobras desenvolvidas posteriormente a essas zonas são abertas, desarmônicas e apresentam foliação plano axial e charneira segundo 241/72 e 166/02, respectivamente (Figs. 12h, i).

As estruturas deformacionais relativas à $\mathrm{D}$ refletem um campo de esforços com orientação geral $\mathrm{NNE} / \mathrm{SSW}$, ao passo que as da fase $\mathrm{D}_{\mathrm{p}}$ refletem esforços orientados na direção WSW/ENE, aproximadamente ortogonais ao primeiro. A interferência tectônica entre as dobras das fases de deformação $\mathrm{D}_{\mathrm{a}}$ e $\mathrm{D}_{\mathrm{p}}$ permite o desenvolvimento do padrão "Domos e Bacias". Esse padrão pode ser observado tanto no embasamento quanto nas unidades da cobertura metassedimentar.

Domínio Estrutural II O Domínio II, situado na porção oeste da sinclinal (Fig. 9), engloba o embasamento, parte das rochas do Complexo Lagoa Real, parte das unidades Velhas e Rio dos Remédios e a totalidade da unidade Pastinho. Nele, predominam as estruturas do estágio $\mathrm{D}_{\mathrm{pl}} \mathrm{O}$ Domínio II representa a porção da Sinclinal de ltuaçu diretamente afetada pela zona de cisalhamento João Correia-Barra do Mendes, uma estrutura que inicia a sua atividade na etapa $D_{p 1}$ e prossegue na etapa seguinte, envolvendo as unidades de cobertura e o substrato cristalino. Trata-se de uma zona de cisalhamento dúctil-rúptil, com movimento preferencialmente destral reverso.

No embasamento, formaram-se, no estágio $\mathrm{D}_{\mathrm{pl}}$, zonas de cisalhamento destral-reversas (sugerido por estruturas $\mathrm{S} / \mathrm{C}$ ) às quais se associa uma foliação metamórfica/milonítica cuja atitude modal é 260/75 (Fig. 13a). A lineação de estiramento, presente nessa foliação e marcada pela biotita e hornblenda, posiciona-se em 202/27 (Fig. 13b). Tais zonas de cisalhamento progri- dem para sul, interceptando estruturas da fase $\mathrm{D}_{\mathrm{a}}$.

Nas unidades da cobertura, os estágios $\mathrm{D}_{\mathrm{p} 1}^{\mathrm{a}}$ e $\mathrm{D}_{\mathrm{p} 2}$ estão representados pelo amplo desenvolvimento da zona de cisalhamento dúctil-rúpteis João Correia-Barra do Mendes, de médio a alto ângulo (Fig. 13), com movimento destral-reverso e orientação preferencial entre 236/38 e 251/68 (Fig. 13c). A lineação de estiramento a ela associada é de baixa obliqüidade e se alinha, preferencialmente, na direção 220/20 (Fig. 13d). As dobras associadas com a zona de cisalhamento em questão são isoclinais e, freqüentemente, apresentam-se transpostas por aquelas estruturas. Apesar da intensa deformação das unidades envolvidas, ainda é possível recuperar feições do acamamento primário que demonstram a presença de inversões estratigráficas. A atitude das charneiras das dobras $\mathrm{D}_{\mathrm{p} 1}$ e $\mathrm{D}_{\mathrm{p} 2}$ é 300/01 (Fig. 13e). As estruturas observadas nesse domínio marcam a ascensão do embasamento sobre as rochas metassedimentares do Grupo Paraguaçu.

Domínio Estrutural III O Domínio III, que engloba o setor leste da sinclinal, inclui somente rochas do Supergrupo Espinhaço, que são: parte das unidades Velhas, Pastinho e Rio dos Remédios e as Unidades Morro do Ouro, Serra da Cabeça Inchada, Fazenda Corcovado e Riacho das Covas. Esse domínio é caracterizado pela mais baixa intensidade de deformação.

No limbo leste da Sinclinal de Ituaçu, as rochas repousam diretamente sobre o embasamento. Nesse domínio, a deformação é baixa a inexistente e as feições sedimentares encontram-se muito bem preservadas. As estruturas relacionadas à fase de deformação $D_{p}$ são as mais expressivas. As zonas de cisalhamento inter e intraestratais do estágio $\mathrm{D}_{\text {pdesc }}$ desenvolvem foliação metamórfica e lineação de estiramento que se orientam, preferencialmente, segundo 254/26 e 255/26, respectivamente (Figs. 14a, b). Dobras abertas afetam as zonas de cisalhamento previamente nucleadas e, na Unidade Velhas, essas estruturas desenvolvem foliação plano axial, cuja orientação é 252/42 (Figs. 14c). Seus eixos posicionam-se em 162/13 (Fig. 14d). Zonas de cisalhamento de médio a alto ângulo da fase $\mathrm{D}_{\mathrm{p} 2}$ cortam as grandes dobras do Domínio III. Essas zonas apresentam foliação metamórfica e lineação de estiramento de alta obliqüidade orientadas, preferencialmente, segundo 259/67 e 250/34, respectivamente (Figs. 14e, f). Destacam-se as zonas de cisalhamento da serra do Geral e Tanhaçu (Fig. 4). A sua nucleação marca o envolvimento do embasamento na deformação da cobertura durante a fase $\mathrm{D}_{\mathrm{p}}$. No extremo sudoeste do sinclinal, foi reconhecida uma lineação de estiramento disposta segundo 210/12 à qual se superimpõe a lineação da fase $\mathrm{D}_{\mathrm{p}}$. Esse fato sugere que as zonas de cisalhamento supracitadas podem ter sido nucleadas durante $\mathrm{D}_{\mathrm{a}}$ e que foram reaproveitadas durante as fases tardias de deformação $\mathrm{D}_{\mathrm{p}}$.

Embora predominem as estruturas da fase $D_{p}$, dobras associadas com a fase $\mathrm{D}_{\mathrm{a}}$ também foram reconhecidas no Domínio III. Essas podem ser observadas ao longo da BR-142, que liga as cidades de Ituaçu e 


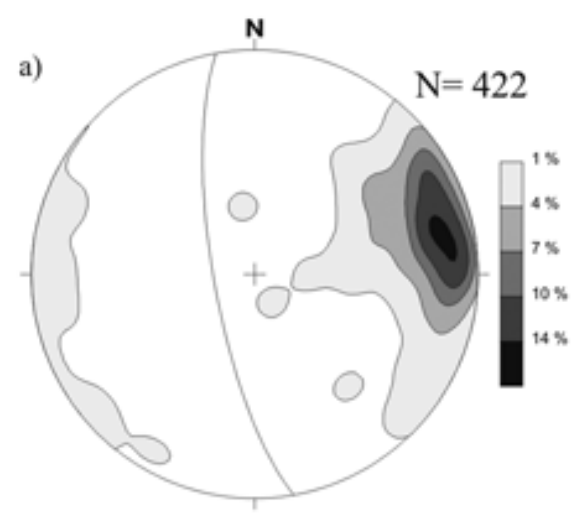
Foliação milonitica- $\mathrm{S}_{p 1}$ Embasamento Zona de cisalhamento Sinclinal de Ituaçu Dominio II Máximo: 260/75

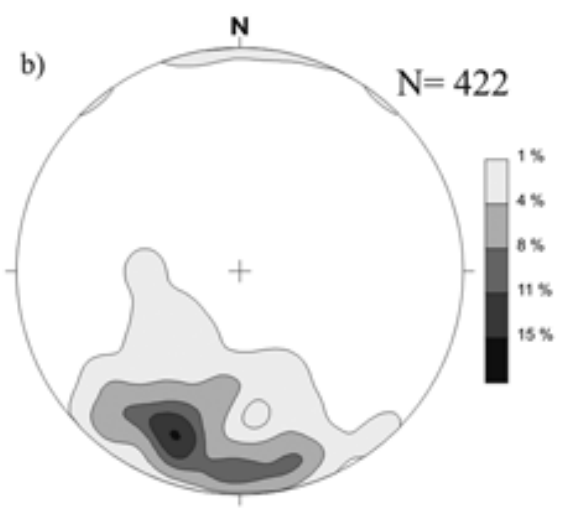

Lineação de estiramento - $L x_{p 1}$ Embasamento Zona de cisalhamento Sinclinal de Ituaçu Domínio II Máximo: 202/27

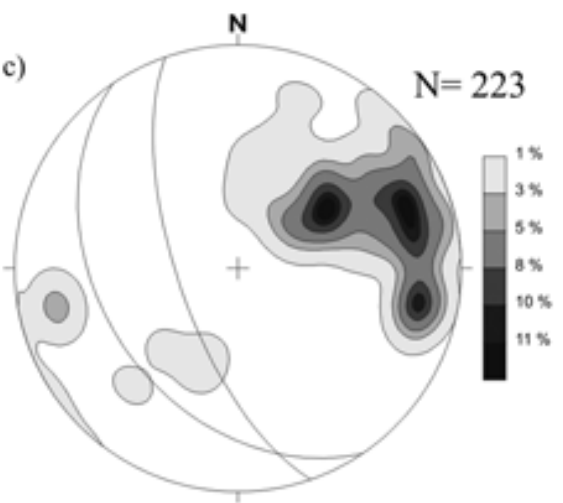

Foliação milonítica - $\mathrm{S}_{\mathrm{p}}$ Cobertura sedimentar Zonas de cisalhamento Sinclinal de Ituaçu Domínio II Máximos: 236/38 // 251/68
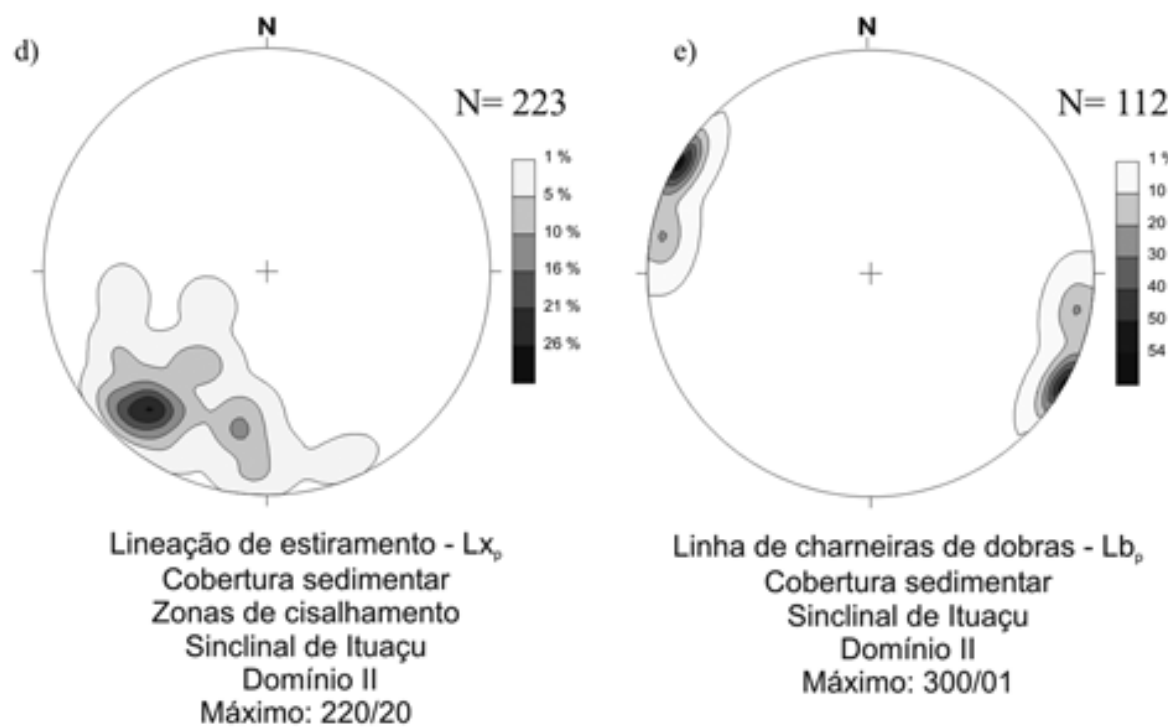

Figura 13 - Diagramas estereográficos sinópticos (Hemisfério inferior) das estruturas $D_{p}$ presentes no Domínio II.

Barra da Estiva. Sua orientação geral é segundo E-W.

METAMORFISMO E PROCESSOS DEFORMACIONAIS Assim como a deformação, o metamorfismo diminui de oeste para leste na Sinclinal de Ituaçu. No limbo leste da sinclinal estudada, o metamorfismo praticamente inexiste. Já no limbo oeste, ele está preferencialmente concentrado em zonas de cisalhamento. Não foi verificada nenhuma variação no metamorfismo no sentido norte-sul.

No embasamento foram observadas duas associações metamórficas. A primeira, $\mathrm{M}_{1 \mathrm{p}}$, está associada com as foliações da fase $\mathrm{D}_{\mathrm{a}}$ e da etapa $\mathrm{D}_{\mathrm{p} 1}$. Essa associação é de fácies anfibolito e é marcada por quartzo, microclina, plagioclásio, biotita e hornblenda. A formação da foliação envolve processos de deformação plástica e recristalização dinâmica por rotação de subgrãos em quartzo e feldspatos. A segunda associação, $M_{1 \mathrm{r}}$, é regressiva, está relacionada com as zonas de cisalha- mento da etapa $\mathrm{D}_{\mathrm{p} 2}$ e é composta por clorita, mica branca e quartzo, indicando condições de fácies xisto verde. Os processos deformacional-metamórficos associados com o desenvolvimento dessas zonas são o microfraturamento de feldspatos, o deslizamento friccional dos fragmentos, hidrólise de feldspatos, deformação plástica e dissolução do quartzo.

Nas unidades de cobertura, o metamorfismo associado às duas fases de deformação reconhecidas é marcado por uma associação mineralógica constituída, essencialmente, por mica branca, clorita, quartzo, calcita. Tal associação indica condições de fácies xisto verde.

Os principais processos deformacionais observados nas rochas do Supergrupos Espinhaço e São Francisco estão associados à transferência de solução (solution transfer). A dissolução acontece, preferencialmente, na interface quartzo/mica e em carbonatos. 

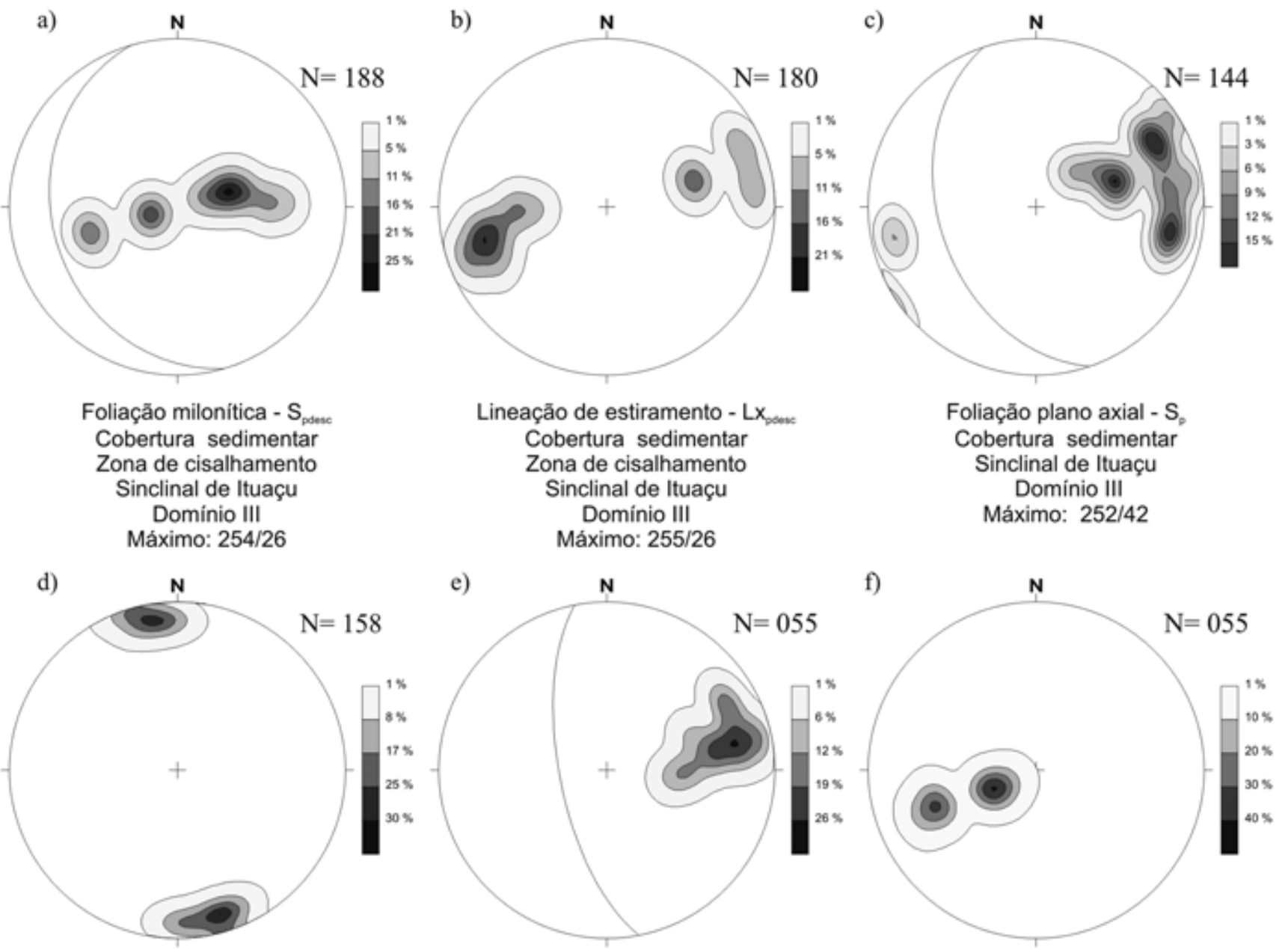

Linha de charneiras de dobras - Lb

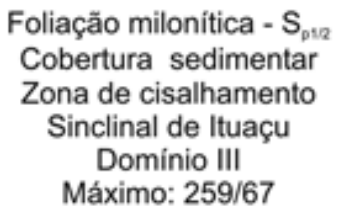

Lineação de estiramento - $L x_{012}$ Cobertura sedimentar Zona de cisalhamento Sinclinal de Ituaçu Domínio III Máximo: $250 / 34$

Figura 14 - Diagramas estereográficos sinópticos (Hemisfério inferior) das estruturas associadas com a fase deformacional $D_{p}$ presentes no Domínio III.

MODELO DE EVOLUÇÃO TECTÔNICA PARA A SINCLINAL DE ITUAÇU Na Sinclinal de Ituaçu podem ser reconhecidas todas as fases de inversão da porção sul do Aulacógeno do Paramirim. Não foram encontradas discrepâncias entre os acervos estruturais das rochas dos grupos Paraguaçu e Una, que representam as unidades mais velha e mais nova da região, respectivamente. Isto faz com que a inversão da porção sul do aulacógeno tenha uma idade máxima neoproterozóica. O registro estrutural armazenado nas rochas dos supergrupos Espinhaço e São Francisco demonstram a existência de duas fases de deformação compressionais distintas $\left(\mathrm{D}_{\mathrm{a}}\right.$ e $\left.\mathrm{D}_{\mathrm{p}}\right)$, cujas estruturas possuem orientações aproximadamente ortogonais entre si.

Brito-Neves \& Pedreira (1992) já haviam reconhecido a presença de duas fases deformacionais na Sinclinal de Ituaçu. Entretanto, a relação cronológica entre as duas gerações de estruturas proposta por esses autores é antagônica à que é aqui apresentada. Segundo eles, as estruturas NS, equivalentes às estruturas $\mathrm{D}_{\mathrm{p}}$, seriam as mais antigas e anteriores ao Grupo Bambuí. As estruturas $\mathrm{EW}$, por outro lado, equivalentes à fase $\mathrm{D}_{\mathrm{a}}$, seriam posteriores e refletiriam a tectônica brasiliana da margem do Cráton do São Francisco.

A partir das relações de truncamento estudadas no Domínio I da sinclinal em questão pode-se afirmar que as estruturas da fase $\mathrm{D}_{\text {a }}$ sa mais antigas do que as da fase $\mathrm{D}_{\mathrm{p}}$ (Fig. 15a). Os indicadores cinemáticos observados em afloramento mostram que as estruturas $\mathrm{D}_{\mathrm{a}}$ refletem transporte tectônico dirigido de SSW para NNE. No embasamento, o registro dessa fase deixa de existir a partir da altura do paralelo $14^{\circ} 00^{\prime} \mathrm{S}$. Na cobertura, entretanto, o seu registro persiste até o paralelo $13^{\circ} 40^{\prime} \mathrm{S}$, ao norte da cidade de Ituaçu. Essas estruturas possuem 

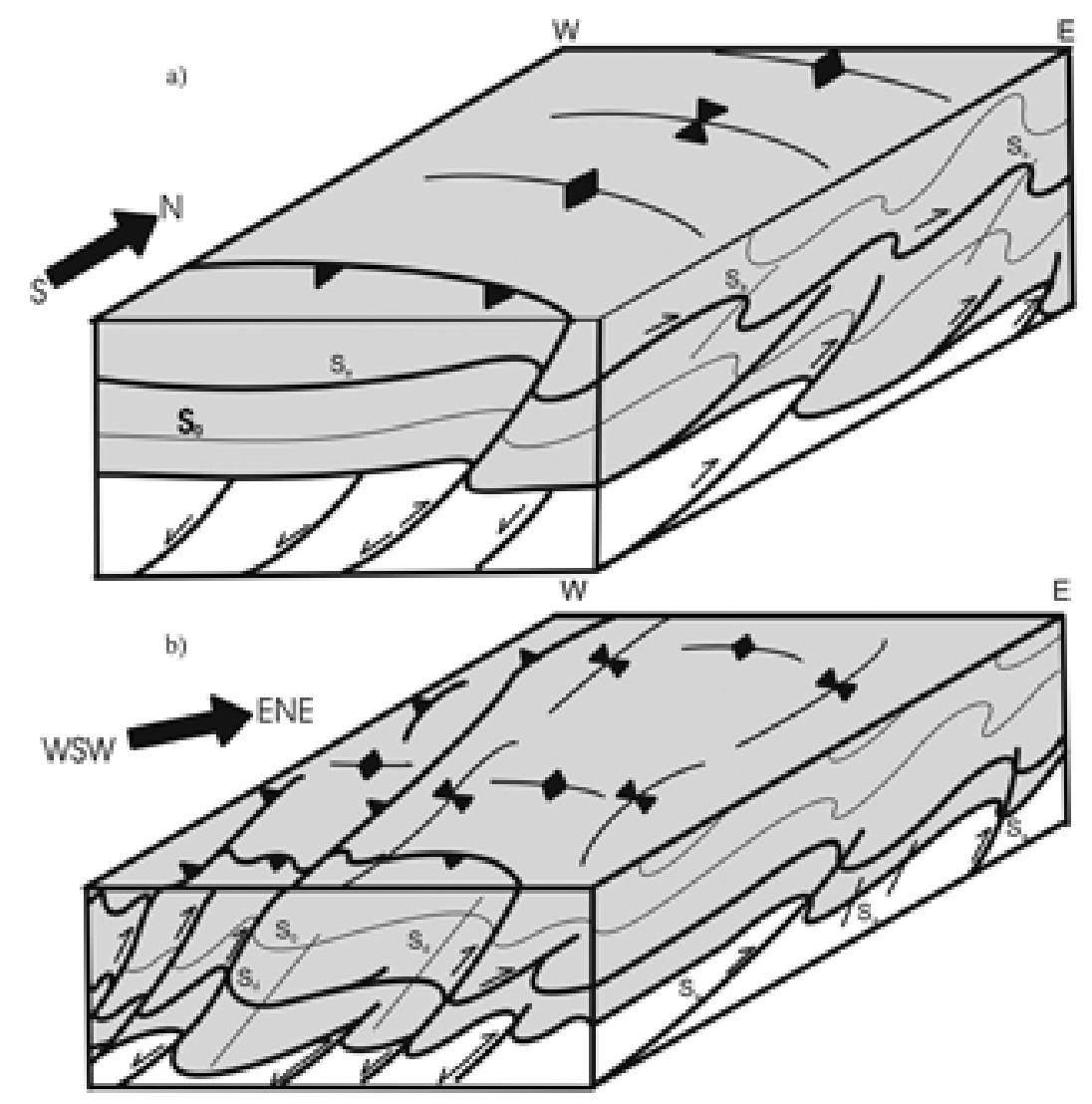

$\square$ Embasamento cristalino

Supergrupos Espinhaço e Sāo Francisco

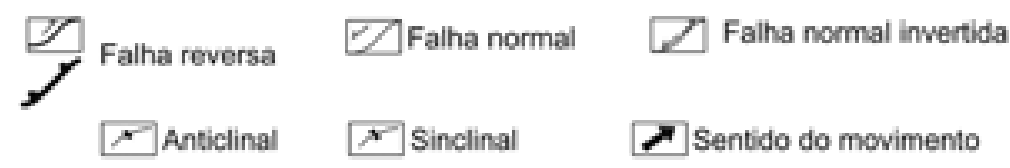

S. Acamamento primário $\mathbf{S}$, S, Foliaçōes miloníticas

Figura 15 - Modelo de evolução tectônica para a Sinclinal de Ituaçu.

o mesmo significado que, na parte norte do aulacógeno, têm as estruturas vergentes para sul, documentadas por Lagoeiro (1990). Elas refletem a propagação, nas unidades da cobertura, das frentes orogênicas brasilianas que margeiam a porção sudeste do Cráton do São Francisco. Ao contrário da porção norte do aulacógeno, as estruturas com orientação WNW/ESE, da fase $\mathrm{D}_{\mathrm{a}}$, precedem a formação dos elementos tectônicos dominantes $\mathrm{D}_{\mathrm{p}}$.

$\mathrm{A}^{\mathrm{p}}$ fase seguinte, $\mathrm{D}_{\mathrm{p}}$, com movimentos dirigidos para leste, marca a época de inversão frontal do Aulacógeno do Paramirim (Fig. 15b). Essa fase está registrada pela formação do cinturão de dobramentos e cavalgamentos da Chapada Diamantina. Essas estruturas foram também observadas nas rochas do Complexo Lagoa Real e na Saliência do Rio Pardo, como descrito por Cruz \& Alkmim (2006).

Durante a inversão do Aulacógeno do Paramirim, a deformação das unidades da cobertura se inicia por meio do desenvolvimento de zonas de cisalhamen- to inter e intraestratais, que marcam a fase inicial dos descolamentos. A presença dessas estruturas demonstra que o acamamento tornou-se mecanicamente ativo, acomodando boa parte da deformação. Em seguida, elas são dobradas e cortadas por zonas de cisalhamento de médio a alto ângulo que marcam a fase de envolvimento do embasamento na deformação da cobertura. Essas zonas representam antigas falhas normais que foram invertidas durante a compressão $\mathrm{D}_{\mathrm{a}}$ e $\mathrm{D}_{\mathrm{p}}$. Modelo semelhante a esse foi sugerido por Danderfer $\mathrm{F}^{\mathrm{o}}$ (1990) e Alkmim \& Danderfer Fo (1995) para as demais áreas da Chapada Diamantina.

CONCLUSÕES (1) Na Sinclinal de Ituaçu dois conjuntos de estruturas cortam igualmente as rochas do embasamento, do Complexo Lagoa Real, do Supergrupo Espinhaço e do Supergrupo São Francisco. Dessa forma, a idade máxima dessas estruturas é neoproterozóica: (2) O primeiro conjunto de estruturas tem orientação WNW/ESE e vergência para NNE. Pela relação com 
as estruturas desenvolvidas nas rochas do Grupo Macaúbas, no limite sudeste do Cráton do São Francisco, sugere-se que elas marcam a fase inicial de formação da Faixa Araçuaí. O segundo, com orientação NNWSSE, reflete a fase de inversão frontal do Aulacógeno do Paramirim e apresentam polaridade para leste: (3) A deformação compressiva das rochas metassedimentares de preenchimento do aulacógeno, em ambas as fases, inicia-se com o desenvolvimento de estruturas nucleadas acima da interface embasamento-cobertura. Somente em um estágio posterior é que o embasamento é envolvido na deformação. Durante esse envolvimento, estruturas antigas do embasamento são reativadas e/ ou invertidas. Tal fato sugere que o limite convencional proposto por Almeida (1977) para o limite sudeste do Cráton do São Francisco deva ser revisto.
Agradecimentos Os autores gostariam de expressar seus agradecimentos à Companhia Baiana de Pesquisa Mineral (CBPM), à Industrias Nucleares do Brasil (INB), à UFOP, à UFBA e à Companhia de Pesquisa de Recursos Minerais (CPRM-SUREG-Salvador) pelo apoio durante a realização desta pesquisa. Além disso, os autores agradecem aos revisores anônimos. S.C.P. Cruz foi contemplada pelo $\mathrm{CNPq}$ com uma bolsa durante o programa de Doutorado (Processo no 140739/2000-9) e de Pós-Doutorado Júnior (Processo no 150127/2005-7). Além disso, foi contemplada com Bolsa de Pós-Doutorado 1 da FAPESB (Termo de Outorga 2083/2006) e pelo Projeto Universal do CNPq (Processo 475092/2004-0). F.F.Alkmim recebe auxílio do CNPq na forma de bolsa de produtividade em pesquisa (Processo no 300833/99-7).

\section{Referências}

Alkmim F.F. 2004. O que faz um cráton um cráton? O Cráton do São Francisco e as revelações almeidianas ao delimitá-lo. In: V. Mantesso-Neto, A. Bartorelli, C.D.R. Carneiro \& B.B. Brito-Neves (eds.) Geologia do Continente Sul-americano: evolução da obra de Fernando Flávio de Almeida, Editora Beca, p. 1-17-35.

Alkmim F.F., Brito Neves B. B. \& Alves J. A. C. 1993. Arcabouço tectônico do Cráton do São Francisco - uma revisão. In: J.M. Dominguez \& A. Misi (eds.) O Cráton do São Francisco. Reunião Preparatória do II Simpósio sobre o Cráton do São Francisco. Salvador, SBG/ Núcleo BA/SE/SGM/CNPq, p. 45-62.

Alkmim F.F. \& Danderfer Fo A. 1995. Duas fases da evolução dos cinturões de dobramentos e empurrões e sua expressão na faixa Araçuaí (MG) e na Chapada Diamantina (BA). In: SBG, Simp. Nac. Est. Tect., 5, Anais, p. 1-2.

Almeida F.F. 1977. O Cráton do São Francisco. Rev. Bras. Geoc., 4:349-364.

Babinsk M., Van Schmus W.R., Chemale J.R.F., Brito Neves B.B. \& Rocha A.D. 1993. Idade isocrônica $\mathrm{Pb} / \mathrm{Pb}$ em rochas carbonáticas da Formação Caboclo em Morro do Chapéu, BA. In: SBG, Simp. Crat. S. Franc., 2, Anais, p. 160-163.

Babinski M., Brito-Neves B.B., Machado N., Noce C.M., Ulhein A. \& Van Schumus W.R. 1994. Problemas na metodologia $\mathrm{U} / \mathrm{Pb}$ em zircões de vulcânicas continentais: o caso do Grupo Rio dos Remédios, Supergrupo Espinhaço, no estado da Bahia. In: SBG, Cong. Bras. de Geol., Boletim de Resumos Expandidos, 2, p. 409-410.

Barbosa J.S.F \& Dominguez J.M.L. (Eds). 1996. Mapa Geológico do estado da Bahia. Escala: 1.000.000. Texto explicativo, Salvador, $382 \mathrm{p}$.

Bastos-Leal L.R. 1998. Geocronologia U/Pb (Shrimp), ${ }^{207} \mathrm{~Pb}{ }^{206} \mathrm{~Pb}, \mathrm{Rb}-\mathrm{Sr}$, Sm-Nd e K-Ar dos Terrenos GranitoGreenstone do Bloco do Gavião: Implicações para Evolução arquena e proterozóica do Cráton do São Francisco, Brasil. Tese de Doutorado, Instituto de Geociências, Universidade Estado de São Paulo, 178 p.

Bento R.V. 2001. Análise estrutural das relações de contato entre as litologias do Vale do Paramirim e da borda oes- te da Chapada Diamantina, SW do estado da Bahia. In: SBG/BA-SE, Simpósio Nacional de Estudos Tectônicos, 7, Anais, p. 135-138.

Brito-Neves B.B. \& Pedreira A. 1992. Primeiras evidências de tectônica de antepaís na borda sul oriental da Chapada Diamantina. In: SBG/SGM, Simp. Reg. Geol. BahiaSergipe, 1, Anais, p. 121-125.

Brito-Neves B.B., Cordani U.G. \& Torquato J.R.F. 1980. Evolução Geocronológica do Pré-Cambriano no estado da Bahia. In: Inda H.A.V. \& Duarte. F.B. (orgs.) Geologia e Recursos Naturais do Estado da Bahia. Textos Básicos, 3, Salvador, SME/COM, pp.: 101.

Cordani U.G. 1973. Evolução Geológica pré-cambriana da faixa costeira do Brasil, entre Salvador e Vitória. Tese de Livre Docência, Instituto de Geociências, Universidade de São Paulo, 312 p.

Cordani U.G., Iyer S.S., Taylor P. N., Kawashita K., Sato K. \& McReath I. 1992. Pb-Pb, Rb-Sr, and K-Ar systematic of the Lagoa Real uranium province (south-central Bahia, Brazil) and the Espinhaço Cycle (ca. 1.5-1.0 Ga). J. South Am. Earth Sci., 1:3-46.

Cordani U.G., Sato K. \& Marinho M.M. 1985. The geologic evolution of the ancient granite-Greenstone terrane of central-southern Bahia Brazil. Precambrian Res., 27:187-213.

Costa P.H.O., Andrade A.R.F., Lopes G.A.C. \& Souza S. L. 1985. Projeto Lagoa Real-Mapeamento Geológico 1:25.000. CBPM/NUCLEBRAS/SME, v.1, 455 p.

Cruz S.C.P. \& Alkmim F.F. 2002. O Arcabouço Estrutural dos Gnaisses Lagoa Real na Porção Sul do Corredor do Paramirim (BA): Evidencias do Envolvimento do Embasamento do Cráton do São Francisco Durante a Interação Brasiliana Entre o Corredor do Paramirim e a Faixa Araçuaí- Oeste Congo. In: SBG/NNE, Cong. Bras. Geol., 46, Anais, p. 301.

Cruz S.C.P. 2004. A interação tectônica entre o Aulacógeno do Paramirim e o Orógeno Araçuaí-Oeste Congo. Tese de Doutorado, Departamento de Geologia, Universidade Federal de Ouro Preto, 503 p.

Cruz S.C.P., Martins V.B., Santana O.S, Almeida J.S., Dias 
V.M. \& Martins C.F.N. 1998. Geologia e Evolução tectônica do braquissinclinal de Água Quente, Chapada Diamantina Ocidental, Bahia, Brasil. In: SBG/NMG, Congresso Brasileiro de Geologia, 40, p. 404.

Cruz S.C.P. \& Alkmim F.F. 2006. The tectonic interaction between the Paramirim Aulacogen and the Araçuaí Belt, São Francisco Craton region, Eastern Brazil. (no prelo).

Danderfer Fo A. 1990. Análise estrutural descritiva e cinemática do Supergrupo Espinhaço na região da Chapada Diamantina (BA). Dissertação de Mestrado, Departamento de Geologia, Universidade Federal de Ouro Preto, $99 \mathrm{p}$.

Danderfer Fo A. 2000. Geologia sedimentar e evolução tectônica do Espinhaço Setentrional, estado da Bahia. Tese de Doutorado, Instituto de Geociências, Universidade Federal de Brasília, 497 p.

Dominguez J.M.L. 1996. As coberturas plataformais do Proterozóico médio e superior. In: J.M.L. Dominguez \& J.S.F. Barbosa (eds.) Mapa Geológico do Estado da Bahia, Texto Explicativo, SGM, p. 105-125.

Guimarães J.T. 1996. A Formação Bebedouro no Estado da Bahia: Faciologia, Estratigrafia e Ambiente de Sedimentação. Dissertação de Mestrado, Instituto de Geociências, Universidade Federal da Bahia, 155 p.

Jardim-de-Sá E.F., Bartels R.L., Brito Neves B.B. \& McReath I. 1976. Geocronologia e o modelo tectonomagmático da Chapada Diamantina e do Espinhaço Setentrional, Bahia. In: SBG, Cong. Bras. Geol., 29, Anais, p. 205-227.

Lagoeiro L.E. 1990. Estudo das deformações nas seqüências carbonáticas do Grupo Una na região de Irecê, $B A$. Dissertação de Mestrado, Departamento de Geologia, Universidade Federal de Ouro Preto, $150 \mathrm{p}$.

Leão Z.M.A.N., Dominguez J.M.L. \& Camargo S.L. 1992. Sedimentação carbonática marinha rasa no Pré-Cambriano: sobre a validade de aplicação de modelos de fácies desenvolvidos para o Fanerozóico. In: SBG/NMG, Simp. Geol. Minas Gerais, 4, Anais, p. 103-104.

Lobato L. \& Fyfe W. 1990. Metamorphism and mineralization at Lagoa Real, Bahia, Brasil. Econ. Geol., 5:968989.

Macedo M.H. \& Bonhomme, M.G. 1984. Contribuição a cronoestratigrafia das Formações Caboclo, Bebedouro e Salitre na Chapada Diamantina (BA) pelos métodos RB-Sr e K-Ar. Rev. Bras. Geoc., 3:153-163.

Marinho M.M. 1991. Le sequence Volcano-Sedimentaire de Contendas Mirante et la Bordure Ocidentale du Bloc de Jequié (craton du São Francisco, Brésil): um example de transition Archeen-Proterozoic. These de doctorat, Université de Clemont-Ferrand, 257 p.

Martin H., Peucat J.J., Sabaté P. \& Cunha J.C. 1991. Um segment de croûte continentale d'Age archéean ancien (3.5 millards d'années): lê massif de Sete Voltas (Bahia, Brésil). C.R. Acad. Sci. Phis., 313:531-538.

Maruejol P., Cuney M., Fuzikawa K., Maria Netto A. \& Poty B. 1987. The Lagoa Real Subalkaline Granitic Complex (South Bahia, Brazil): A Source for Uraniun Mineralizations Associated With Na-Ca Metassomatism. Rev. Bras.
Geoc., 4:578-594.

Menezes Fo N.R. 1996. Geologia do Sinclinal de Ituaçu (Escala 1:100.000). Dissertação de Mestrado, Instituto de Geociências, Universidade Federal da Bahia, 191 p.

Misi A. \& Veizer J. 1996. chemostratigraphy of neoproterozoic carbonate sequences of the Una Group, Irecê Basin, Brazil. In: SBG/NBA-SE, Cong. Bras. Geol., 39, Anais, p. 487-489.

Moutinho da Costa L.A. \& Inda H.A. V. 1982. O Aulacógeno do Espinhaço. Ciências da Terra, 2:13-18.

Pedreira A.J.C.L. 1994. O Supergrupo Espinhaço na Chapada Diamantina centro oriental, Bahia: Sedimentologia, estratigrafia e tectônica. Tese de Doutorado, Instituto de Geociências, Universidade Estadual de São Paulo, 126p.

Pedrosa-Soares A.C., Noce C.M., Wiedemann C.M. \& Pinto C.P. 2001. The Araçuaí-West-Congo Orogen in Brazil: an overview of a confined orogen formed during Gondwanaland assembly. Precambrian Res., 1(4):307-323.

Pimentel M.M., Machado N. \& Lobato L.M. 1994. Geocronologia $\mathrm{U} / \mathrm{Pb}$ de rochas graníticas e gnáissicas da região de Lagoa Real, Bahia, e implicações para a idade da mineralização de urânio. In: SBG, Cong. Bras. Geol., 38, Boletim de Resumos Expandidos, p. 389-390.

Santos-Pinto M.A. 1996. Le recyclage de la croúte continentale archéenne: Exemple du bloc du Gavião - Bahia, Bresil. Doctor of Philosophy Thesis, Geociences Rennes. $193 \mathrm{p}$.

Schobbenhaus C. 1993. O Proterozóico Médio do Brasil com ênfase à região centro-leste: Uma revisão. Tese de Doutorado, Freiburger Geowiss. Beitr, 166 p.

Schobbenhaus C. 1996. As tafrogêneses superpostas Espinhaço e Santo Onofre, estado da Bahia: Revisão e novas propostas. Rev. Bras. Geoc., 4:265-276.

Schobbenhaus C., Campos D.A., Derze G.R. \& Asmus H.E. 1981. Mapa Geológico do Brasil e da Área Oceânica Adjacente, Incluindo Depósitos Minerais, (Escala 1:2.500.000). DNPM, Brasília.

Toulkeridis T., Babinski M., Buchwaldt R., Brito Neves B.B., Todt W. \& Santos R. 1999. Are varangian or sturtian the glacial deposits on the São Francisco craton? Evidence from determination of sedimentary rocks and minerals of the Neoproterozoic Una Group. In: South Amer. Symp. Isotope Geol., 2, Anais, p. 453-456.

Trompette R. 1994. Geology of Western Gondwana (2000500 M.a). Pan-Anfrican-Brasiliano Agregation of South America and Africa. Balkema, Rotterdam, $350 \mathrm{p}$.

Trompette R., Ulhein A., Egydio da Silva M. \& Karmnn I. 1992. The Brasiliano São Francisco Craton revisited (Central Brazil). J. South Am. Earth Sci., 1/2:49-57.

Turpin L., Maruejol P. \& Cuney M. 1988. U-Pb, Rb-Sr and Sm-Nd chronology of granitic basement, hydrotermal albitites and uranium mineralization, Lagoa Real, South Bahia, Brazil. Contrib. Mineral. Petrol., 98:139-147.

Manuscrito CSF-1666 Submetido em 31 de maio de 2006 Aceito em 01 de março de 2007 